Ignace De Keyser

\title{
The Construction of the Genius in 19th-Century Music. The Case of Adolphe Sax
}

In his I86o biography of Sax, Oscar Comettant establishes an intimate link between progress, invention and genius:

"[...] in order to lead humanity on the way of progress, God did not choose the rich, nor always the great of the earth, but rather often obscure and hard-working people endowed by the Almighty with the grace of initiative. [...]

Not only do we enjoy the presence of these profound minds that discover new paths, but we recognise their services and we look for ways to reward them. [...]

It has finally been recognised that a country is great and prosperous only by its men of genius. We have counted the nations and found that their wealth was proportional to the protection given to inventors."

“[...] pour diriger l'humanité dans la voie du progrès, ce ne sont point les riches que Dieu a choisis; ce ne sont pas toujours les grands de la terre non plus; ce sont le plus souvent d'obscurs et laborieux travailleurs dotés par le Tout-Puissant des grâces de l'initiative. [...]

Non seulement on fait grâce de la vie aux profonds esprits qui découvrent des voies nouvelles, mais on reconnaît leurs services et on cherche les moyens de les en récompenser. [...]

On a reconnu enfin qu'un pays n'est grand et n'est prospère que par ses hommes de génie. On a compté les nations, et on a trouvé qu'elles étaient riches en raison directe de la protection accordée aux inventeurs." ${ }^{\text {I }}$

Throughout his biography of Sax, Comettant continuously stresses these three components. His approach resonates down to today. ${ }^{2}$ Although a semantic discussion of "genius" in the $\mathrm{I}^{\text {th }}$ century would be interesting, this paper shall discuss the topic as Sax's contemporaries understood it. An interesting paradigm seems to be the theoretical framework offered by Tia DeNora in her book on the social identity of Beethoven. ${ }^{3}$ According to DeNora, Beethoven's patrons in Bonn and especially in Vienna profited from his new musical style and succeeded in imposing a new canon of musical style and performance on Viennese concert life. Moreover, Beethoven himself very much contributed to the construction of his own aura as a genius.

Oscar Comettant: Histoire d'un inventeur au dix-neuvième siècle. Adolphe Sax, ses ouvrages et ses luttes, Paris I860, p. I93. All English translations by the author.

2 See for example Paul Gilson: Les géniales inventions d'Adolphe Sax, [Brussels] I939 (Brochure programme de l'I.N.R., Série française $N^{\circ}$ 26); J. G. Prod'homme: Un inventeur de génie. Adolphe Sax, père du saxophone, in: L'Illustration, $\mathrm{N}^{\circ}{ }_{5}^{\mathrm{I} 22}$ ( $\mathrm{N}^{\circ}$ spécial, Io May I94I), p. 9; Jean-Pierre Rorive: Adolphe Sax I8I4-I894. Inventeur de génie, Brussels 2004; idem: Adolphe Sax. Sa vie, son génie inventif, ses saxophones, une révolution musicale, Luxembourg 2014.

Tia DeNora: Beethoven and the Construction of Genius. Musical Politics in Vienna, I792-ISo3, Berkeley I995. 
An excellent résumé of Tia DeNora's theoretical framework appeared in her response to a critic, Charles Rosen, in The New York Review of Books:

"Between 1792 and 1803 , the musical field - concert-giving conventions, critical discourse, music technology - was restructured such that Beethoven's unconventional works came to condition the criteria by which they were judged. The result was a virtuous circle within which Beethoven flourished."

DeNora's theoretical framework can also be applied to Sax. Indeed, between I842 and I870, French army bands adopted several formations imagined by Adolphe Sax ${ }^{5}$ - as did the banda at the Paris Opéra under his direction. ${ }^{6}$ The mainstream critical discourse on wind instrument-making in France was focused on Sax's innovations, ${ }^{7}$ and the vertically integrated production that he introduced in Parisian wind instrument-making changed the industrial conditions of production. ${ }^{8}$ One could thus say that, between I842 and I870, "the field of wind instrument making in Paris was restructured such that Sax's unconventional new musical instruments came to condition the criteria by which they were judged. The result was a virtuous circle within which Sax flourished."

How important are competition, networks, the critical discourse and canon in Sax's career?

Competition It is well known that Sax adored launching challenges and competing against rival musicians and makers. Let us consider four of them:

Bachmann Shortly after Sax patented his bass clarinet (I838), he joined the Brussels Société de la Grande Harmonie as a bass clarinet player. Georg Christian Bachmann (I804I842), the first clarinettist of this ensemble and himself a wind instrument maker, 9 cannot

4 Tia DeNora/Charles Rosen: Beethoven's genius. An exchange, in: The New York Review of Books, , Io April I997; see www.nybooks.com/articles/archives/I997/apr/Io/beethovens-genius-an-exchange (25 June 2018).

5 See Malou Haine: Adolphe Sax (I8I4-I894). Sa vie, son oeuvre et ses instruments de musique, Brussels I980, Pp. 98-II5.

6 See Ignace De Keyser: Adolphe Sax and the Paris Opéra, in: Brass Scholarship in Review. Proceedings of the Historic Brass Societp Conference at the Cité de la Musique, Paris I999, Hillsdale NY 2006, pp. I33-I69.

7 Music professionals such as François-Joseph Fétis, Henri Blanchard, Jean-Georges Kastner, Léon Kreutzer, Hector Berlioz, Maurice Bourges and Oscar Comettant, and scientists like Jean-Baptiste Jobard and Félix Savart confirmed the originality of Sax's inventions and affirmed Sax's superiority in the field. See "Writings" in Tables 2 and 3 of the present article, and the corresponding bibliographic references in Table 5 .

8 See Malou Haine: Les facteurs d'instruments de musique à Paris au $\mathrm{Ig}^{e}$ siècle. Des artisans face à l'industrialisation, Brussels I985, pp.69, 7I and 74.

9 Bachmann was born in Paderborn (at that time in Prussia) and married Amélie Louise, a sister of Charles Mahillon; after her death in I839, he then married her younger sister, Jeanne Mahillon. Bachmann produced not only clarinets, but also brasswind instruments. His influence on both Barthélemi 
have been amused by the arrival of this young, talented man. Sax was I8 or ig at that time, and threw down a challenge to his competitor: they would both present their clarinets in public and let the public judge their respective qualities. This is how Comettant dramatised the contest:

"When the day of the concert arrived, there were four thousand people in the hall. Sax began, and truly thunderous applause greeted the young virtuoso. Despite all the admiration for M. Bachmann on the part of the Brussels public, he enjoyed no success when he came in turn to play a solo on his old instrument.

Since then, M. Sax has played all the bass clarinet solos in the Grande Harmonie ropale and the Société philharmonique. We can only add that all the pieces written for M. Adolphe Sax and played by him on the bass clarinet in the Grande Harmonie and the Société philharmonique have not been able to be played since his departure from Brussels, for they present such difficulties."

"Le jour du concert arrivé, i l y avait quatre mille personnes dans la salle. Sax commença, et un véritable tonnerre d'applaudissements accueillit le jeune virtuose. Malgré toute l'estime que le public de Bruxelles professait pour M. Bachmann, ce dernier n'obtint aucun succès, quand il vint, à son tour, exécuter un solo sur l'ancien instrument.

Depuis lors, M. Sax joua tous les solos de clarinette-basse à la Grande Harmonie ropale et à la Société philharmonique. Ajoutons que tous les morceaux écrits pour M. Adolphe Sax et exécutés par lui sur la clarinette-basse à la Grande Harmonie et à la Société philharmonique ne peuvent plus se jouer depuis son départ de Bruxelles, tant ils présentent de difficultés." ${ }^{\text {ז0 }}$

In short, Sax won the contest and he was invited to play the bass clarinet in both the Société de la Grande Harmonie and Société philharmonique in Brussels.

Buteux Sometimes the challenges that Sax made were not followed by a live competition, but instead by a virtual competition in the form of a controversy in the newspapers. That was the case with Claude-François Buteux, the first clarinettist of the Paris Opéra, who apparently offended Sax's pride by saying that his bass clarinet was worth nothing. In an unsigned article in Revue et Gazette des théâtres, Sax suggests that Buteux choose a piece of his liking, and that they should each perform it on their own instrument before an audience. ${ }^{\text {II }}$ Buteux did not reply. However, the article went on to quote positive witness accounts of Sax's clarinets by Hector Berlioz, Georges Kastner, Federico Ricci, Giacomo Meyerbeer, Adolphe Adam, Ambroise Thomas, Michele Carafa and Jacques Fromental Halévy.

and Charles Mahillon must have been considerable; see Ignace De Keyser: De geschiedenis van de Brusselse muziekinstrumentenbouwers Mahillon en de rol van Victor-Charles Mahillon in het ontwikkelen van het historisch en organologisch discours omtrent het muziekinstrument, Ghent [Diss.] 1996, Vol. I, pp. 34-37.

10 See Comettant: Histoire d'un inventeur, p. 8 .

11 "Je propose donc à M. Buteux, première clarinette de l'Opéra, de choisir tel morceau qu'il lui plaira, et lui sur son instrument, et moi sur le mien, nous le jouerons en public." See M. Sax et ses adversaires, in: Revue et Gazette des théâtres, 3 December I843, pp. [II]f. 


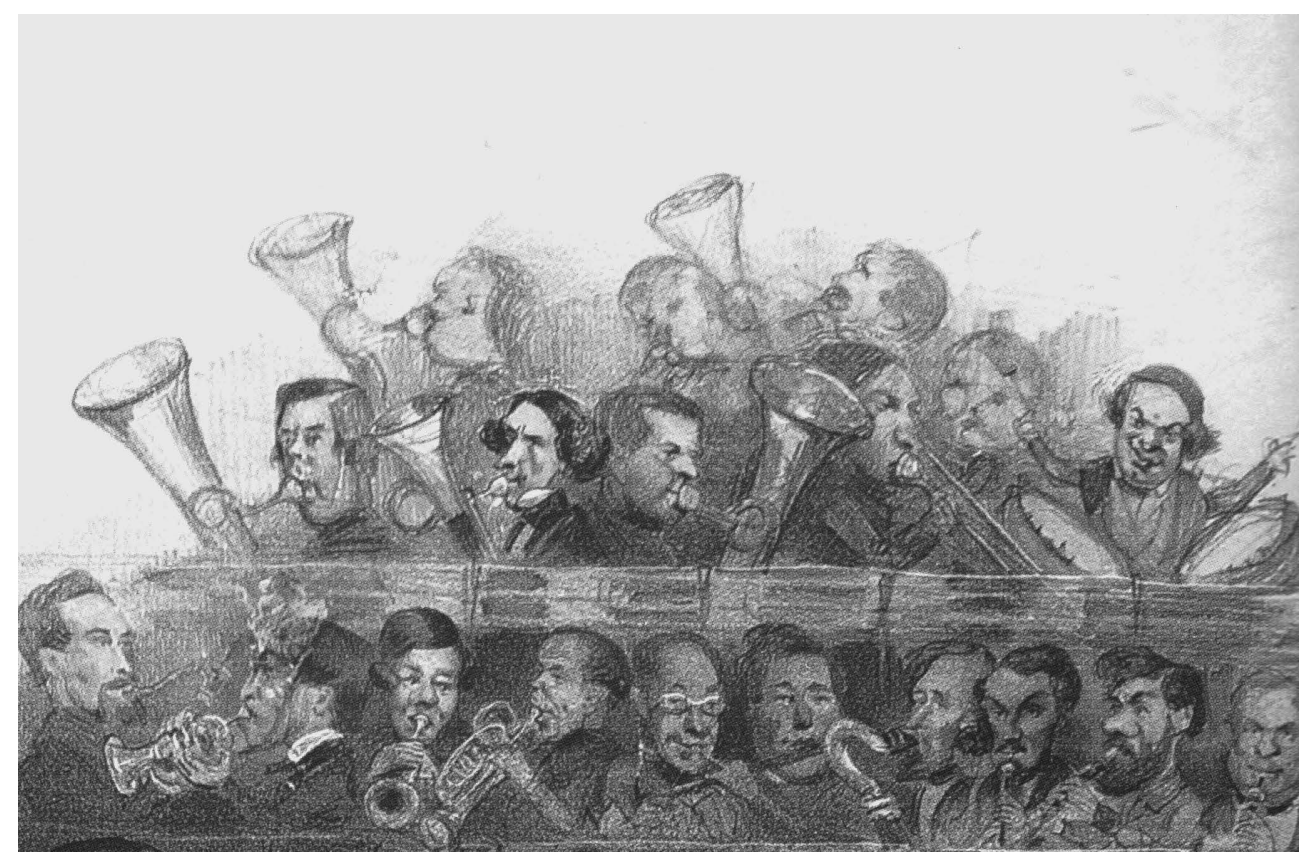

FIGURE I Sax on the bass clarinet and Bachmann on the clarinet (bottom right) in a rehearsal of the Brussels Société de la Grande Harmonie (1842). Notice the presence of four ophicleides and one Russian bassoon. Drawing by Louis-Joseph Ghémar: Dédié à la Société de la Grande Harmonie.

Courtesy of the Library of the Brussels Conservatory

Make your own Saxophone In his defence before the Court of Appeal on I6 February I850, Sax claimed that in I845, one year before patenting his saxophone, he had challenged his competitors to make a saxophone of their own: "You say you know the saxophone. I challenge you to make one, and to do so I give you one year, during which I will not patent it." ${ }^{22}$

There was now radio silence again, which Sax considered to be proof that his competitors were indeed unable to make or imitate the saxophone with the technical knowledge and experience they had.

Champ-de-Mars On several occasions during his Parisian career, ${ }^{\mathrm{I} 3}$ Sax had the opportunity to demonstrate his orchestral concept for wind bands, including saxophones, saxhorns and saxotrombas. The fact that the contest between the rival bands of Michele Carafa and Adolphe Sax at Paris Champ-de-Mars on 22 April I845 became so emblematic

"Vous dites que vous connaissez le Saxophone, je vous défie d'en faire un seul, et pour cela je vous en donne un an, pendant laquelle je ne prendrai pas mon brevet." See Adolphe Sax: Note pour Messieurs les conseillers [ $3^{e}$ Chambre de la Cour d'Appel, I6 février I850], Paris: Simon Dautreville \& Cie [I850], p. 20. See the relevant details in Table 4. 
is partly due to the dramatic circumstances in which it took place ${ }^{\mathrm{I} 4}$ and partly (perhaps mostly) due to the dramatic descriptions given of it, especially by Le Charivari and Oscar Comettant. ${ }^{15}$ Although Sax is at the heart of this contest, he himself seems relatively absent as a protagonist: he refuses to take part in the organising committee, he does not conduct his own band(s), but replaces a missing musician on the bass clarinet, and seems to be absent in the procedure following the contest that will determine the introduction of his band model in the French Army.

Sax's networks Tables I-3 in the appendix contain information on 335 personalities who helped or supported Sax's actions, mainly in Paris. They form three major groups:

- Politicians and the army establishment - see Table I;

- Writers, scientists and artists who supported Sax and/or wrote reports on his musical instruments in industrial exhibitions - see Table 2;

- Music professionals: mainly composers, virtuosos, conductors and music critics, and sometimes people who combined these specialities - see Table 3.

The list is not exhaustive. ${ }^{\mathrm{I}}$ The ratio between the three sub-groups is as follows (see Figure 2). The support given by these sub-groups evolved over time following the shifts in the political system of Sax's time:

- The July Monarchy until I848;

- The I848 Revolution and Second Republic: I848-I852;

- The Second Empire: $1852-1870$;

- The Third Republic: post-I870.

Since the premises of a support for Sax during the Second Empire already started in the years before, the time span between I848 and I870 is treated as one period. On the other hand, no effective support for Sax from the political and army establishment can be confirmed for the period of the Third Republic: it vanished, so to speak, after the Second Empire (see Figure 3). ${ }^{\mathrm{I}}$

14 A month before this contest, on 22 March r845, 3I Parisian wind-instrument makers wrote a letter of protest to the Minister of War; see Haine: Adolphe Sax, p. Ior.

15 See [Anonymous]: Un bulletin moderne. Pour faire suite aux bulletins de la Grande Armée, in: Le Charivari I4/II5 (25 April I845), pp. [I] f.; Comettant: Histoire d'un inventeur, pp. IO2-IIO.

16 Exhaustive research into Sax's networks still has to be done. Excluded from the lists are those people who were hired by Sax for his concerts or for the banda, including the many musicians of his Fanfare and Grande Harmonie.

17 Despite their loss of influence during the Third Republic, several army officials still retained a trace of sympathy for Sax after I870. In the summer of 1874 , General de Lichtlin, the Prince of Joinville, 


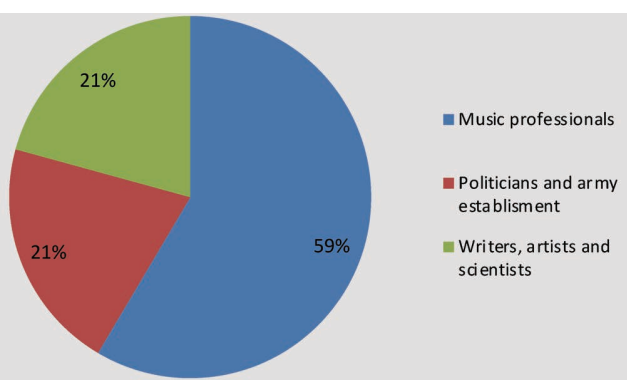

FIgURE 2 Sax's networks.

A statistical overview

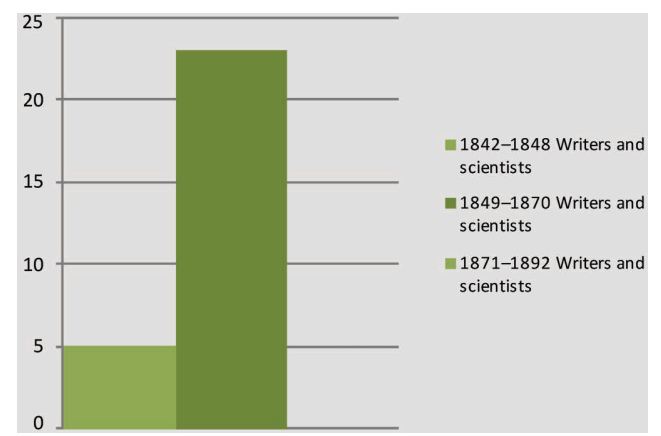

FIgURE 4 Sax's networks.

Writers, artists and scientists (totals)

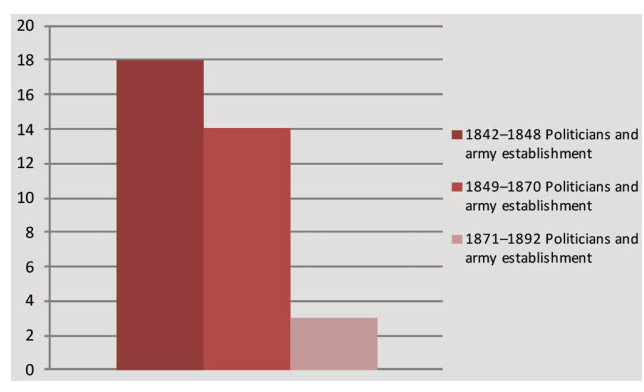

Figure 3 Sax's networks.

Politicians and army establishment (totals)

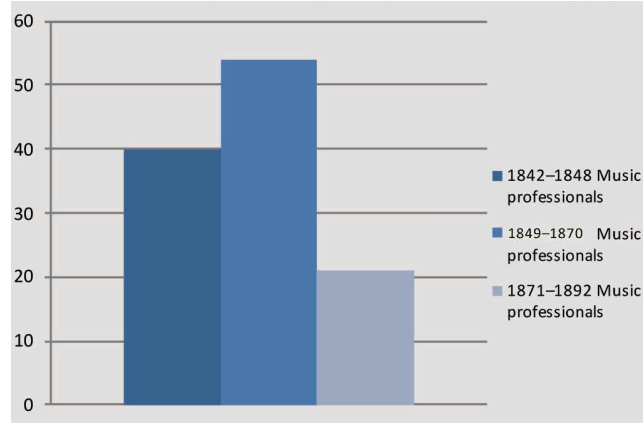

FiguRe 5 Sax's networks.

Music professionals (totals)

Writers, artists and scientists were rather hesitant to give their support to Sax until his merits as an inventor and an innovative musical instrument maker became evident, that is, during the Second Empire (see Figure 4). Scientists such as the mathematician Jules Lissajous, ${ }^{\mathrm{I} 8}$ Jean-Baptiste Jobard ${ }^{\mathrm{I} 9}$ and Nicolas Savart ${ }^{2 \mathrm{O}}$ wrote very positive reports on Sax.

Music professionals represented Sax's most faithful supporters. They remained so, albeit on a reduced level, until the end of his life (see Figure 5).

Commander Piquemal, Captain of Staff Chavaud and General Mellinet contributed to the subscription organised by the newspaper Le Figaro in order to save Sax from bankruptcy; see Table 5 under Le Figaro I87408. The author would like to thank Astrid Herman of Brussels мiм for communicating this.

18 See his report in favour of Sax's nomination as on Officer of the Légion d'honneur, in: Malou Haine: Un réseau d'influence. Les démarches d'Adolphe Sax pour obtenir la croix d'officier de la Légion d'honneur, in: Revue belge de musicologie 70 (20I6), pp. 9-22, here pp. I6f.

19 See Bibliographic Sources under Jobard: Exposition [...] ז 839 .

20 See Bibliographic Sources under Halévy: Rapport d'expertise. Nicolas Savart should not be confounded with his brother, the physicist Félix Savart (I79I-I84I), who gave his name to the savart and to Savart's wheel, and whose particular interest in the violin led him to create an experimental trapezoidal model for that instrument. 
Who were these music professionals?

In the first period, I would call them "general supporters": renowned artists who sympathised with Sax's creative ideas and innovative musical instruments. They included the Director of the Brussels Conservatory François-Joseph Fétis, the composer and music critic Jean-Georges Kastner, and the writer Oscar Comettant. They were unconditional supporters of Sax.

In the second period we find a number of composers who wrote for Sax instruments at the Paris Opéra: Armand Limnander de Nieuwenhove, Léon Gastinel, Charles Gounod, Jacques Fromental Halévy, Giacomo Meyerbeer, Abraham Louis Niedermeyer, Józef Michał Poniatowski, Ambroise Thomas, et cetera. Richard Wagner was obliged to collaborate with Sax, while Giuseppe Verdi, although a reluctant partner to Sax, wrote by far the most beautiful banda score, the "Auto-da-Fé" scene of Don Carlos (I867).

This second period includes the composers who wrote music for Sax's own music editions as well. Some of them are worth considering in more detail. The works of Sax's compagnon de route, Jean-Baptiste Singelée, are relatively well known today, ${ }^{2 \mathrm{I}}$ but those of other composers await rediscovery. The most loyal musician to the case of Sax, JeanGeorges Kastner, integrated Sax instruments in several of his compositions. ${ }^{22}$ Jérôme Savari, ${ }^{23}$ a prolific army band leader (who is confused on occasion with the bassoon maker Nicolas Savary), preached the gospel of the saxophone in army bands throughout France and contributed to the popularisation of that instrument. He must have written considerably more pieces for saxophone and saxophone ensemble than can be deduced from Sax's catalogue of music editions: ${ }^{24}$

- Fantaisie sur le Freischütz for E flat saxophone and piano (1855)

- Première fantaisie sur un thème original for alto saxophone and piano

- Deuxième fantaisie sur un thème original for alto saxophone and piano

- Troisième fantaisie sur un thème original for $\mathrm{B}$ flat saxophone and piano

- Duo for SA or TB saxophone

- Trio for SAB saxophone (dedicated to Kastner)

- Quatuor for SATB saxophones

21 Singelée wrote his compositions for saxophone between the early I850s and I864, mainly as examination pieces for the Paris Conservatoire; see http://fr.wikipedia.org/wiki/Jean-Baptiste_Singel\% $3 \%$ Age and www.singelee.com (25. June 2018).

22 See Table 5 under "Kastner".

23 See www.classicalmusicnow.com/savari.htm, and the raw material for a biographical sketch at http:// saxophonemes.fr/saxophonemes.fr/A_la_recherche_de_Savari.html (25. June 20I8).

24 See "Inventaire des planches lithographiques du fonds d'éditeur dépendant de la faillite d'Adolphe Sax, I878", in Haine: Adolphe Sax, pp. I82-186. 
- Quintetto for SSATB saxophones

- Sextuor for SSAATB saxophones

- Septuor for SSAATtB saxophones

- Octuor for SSAATtBB saxophones

The French composer and pianist Émile Jonas ${ }^{25}$ taught at the Paris Conservatoire. A Sephardic Jew, he was a cantor at the Portuguese Synagogue in the rue Lamartine. He not only wrote for the Sax Fanfare and for saxophone, but he also conducted the Garde Impériale and in that function contributed to the spread of the Sax canon. His compositions were highly praised by Sax himself. In the 1872 Catalogue of his music editions, Adolphe Sax testifies:

"We believe to be useful for the popular instrumental art by strongly recommending to the Musical Societies the newly published Fanfares by Mr. Emile Jonas. These pieces are written with as much science as with taste, and seem to us very suitable for developing the musical knowledge of the performers, from the purely technical point of view as well as from the higher point of view of thought and expression. [...] These fanfares can be performed with or without saxophones."

"Nous croyons être utile à l'art instrumental populaire en recommandant vivement aux Sociétés musicales les Fanfares nouvellement publiées par M. Emile Jonas. Ces morceaux sont écrits avec autant de science que de goût, et nous paraissent très propres pour développer les connaissances musicales des exécutants, tant au point de vue purement technique qu'au point de vue plus élevé de la pensée et de l'expression. [...] Ces fanfares peuvent s'exécuter avec ou sans saxophones." 26

In the last period we mainly find composers for the Opéra, who all included more or less important parts for the Sax banda and/or saxophone in their works. At least six composers among Sax's supporters wrote symphonies. ${ }^{27}$ Unfortunately, none of these works contains parts for Sax instruments.

Two other music professionals, Wagner and Verdi were not especially happy to feature in Sax's network, and Berlioz and Distin were changing sides.

See http://fr.wikipedia.org/wiki/\%C3\%89mile_Jonas (25. June 2018).

26 See Catalogue de musique de la maison Adolphe Sax, 50, rue saint-Georges, Paris [post I872], published in Florence Gétreau: Adolphe Sax éditeur de musique, in: Quatre siècles d'édition musicale. Mélanges offerts à Jean Gribenski, ed. by Joann Élart, Étienne Jardin and Patrick Taïeb, Brussels 20I4 (Études de Musicologie/Musicological Studies, Vol.5), pp. 2II-220, here 2I7-220.

27 Léon Kreutzer: 2 symphonies (I863 an I864); César Franck: $2^{\text {nd }}$ and $3^{\text {rd }}$ symphonies (I872 and I887/88); Léon Gustave Cyprien Gastinel: 2 symphonies (I850 and I888), 2 ouvertures and several symphonic poems; Camille Saint-Saëns: 5 symphonies; Félix-Ludger Rossignol, dit Victorin de Joncières: Symphonie romantique (1873) and La Mer, ode spmphonique (I88r); Émile Paladilhe: Symphonie (1862/63); Gervais Bernard Gaston Salvayre: Symphonie biblique (1882). Georges Bizet's Symphony in C, although written in I855, remained unknown until it was rediscovered in the I930s. On the other hand, Bizet included an alto saxophone in his two Arlésienne suites (I872). 
Berlioz Berlioz defended Sax and his inventions in many of his articles and in his treatise on orchestration. ${ }^{28}$ An ardent supporter of Sax from the beginning, he wrote of him as being a genuine inventor:

"At this moment, Adolphe Sax is making small and large trumpets with cylindrical valves, at all possible pitches both common and uncommon; their sound is excellent and the perfection of their making indisputable. Can one imagine that this young and ingenious artist has the greatest difficulties in holding his own in Paris? In their opposition to him, people are reviving persecutions worthy of the Middle Ages, and which recall exactly the actions undertaken by the enemies of Benvenuto, the Florentine sculptor. They remove his workers, they rob him of his plans, he is accused of madness, they take him to court; with a little more daring, they would kill him. Such is the hatred that inventors always excite among those of their rivals who invent nothing."

"[...] Adolphe Sax fait à cette heure des trompettes à cylindres, grandes et petites, dans tous les tons possibles usités et inusités, dont l'excellente sonorité et la perfection sont incontestables. Croirait-on que ce jeune et ingénieux artiste a mille peines à se faire jour et à se maintenir à Paris? On renouvelle contre lui des persécutions dignes du moyen-âge, et qui rappellent exactement les faits et gestes des ennemis de Benvenuto, le ciseleur florentin. On lui enlève ses ouvriers, on lui dérobe ses plans, on l'accuse de folie, on lui intente des procès; avec un peu plus d'audace, on l'assassinerait. Telle est la haine que les inventeurs excitent toujours parmi ceux de leurs rivaux qui n'inventent rien." ${ }^{29}$

Despite his explicit support for Sax's case, Berlioz almost never used any Sax instruments in his works. ${ }^{30}$ He employs a banda with Sax instruments on three different occasions. In the Marche at the end of the $\mathrm{I}^{\text {st }}$ act of Les Tropens (I856/I858), Berlioz uses a piccolo saxhorn [petit saxhorn suraigu (en sib)] in the first orchestra and, in the second orchestra, a fanfare with two soprano saxhorns, one alto, a tenor and a double bass. The Petit Saxhorn suraigu comes back in the "Premier" and "Troisième Tableau" of Act v. In his Te Deum, he again uses a piccolo saxhorn [petit saxhorn suraigu]. In one of his last works, the I864

28 See Malou Haine: Hector Berlioz, chantre inconditionnel d'Adolphe Sax, in: Revue belge de musicologie 70 (2016), pp. 23-43. Between I842 and I86I, Berlioz refers 46 times to Sax in his musical critics published in the Journal des débats politiques et litéraires. See the details in Hector Berlioz. Critique musicale, ed. by Anne Bongrain and Marie-Hélène Coudroy-Saghaï, Paris, Vol. 5 (I842-I844), 2004, Vol. 6 (I845I848), 2008 and Vol. 7 (I849-185I), 20I4, and on The Hector Berlioz Website under "Sax", as follows: www.hberlioz.com/search.php?zoom_sort=o\&zoom_query=Sax\&zoom_per_page=Io\&zoom_and=I (25. June 2018).

29 See Hector Berlioz: Feuilleton. Voyage musical en Allemagne (Septième Lettre). A Mademoiselle Louise Bertin. Berlin, in: Journal des débats politiques et littéraires, 8 October i843, pp. [I]f., here p. [I].

30 In I856, Berlioz himself confirmed this attitude in his Mémoires (Post-scriptum du 25 mai): "[...] on me reproche d'abuser les instruments de Sax (sans doute parce que j'ai souvent loué le talent de cet habile facteur). Or, je ne les ai employés jusqu'ici que dans une scène de la Prise de Troie, opéra dont personne encore ne connait une page." - "I am accused of abusing Sax's instruments (probably because I have often praised the talent of this clever instrument maker). However, until now, I only used them in a scene of The Capture of Trop, an opera from which nobody even knows a single page." See www. hberlioz.com/Writings/HBMPS.htm (25 June 2018). 
concert version of the Marche tropenne, Berlioz integrates a complete banda with Sax instruments. In some of his reviews, Berlioz acknowledges that Sax's brass instruments sound too loud:

"[...] then military bands entered on stage, and finally the large Sax instruments, which, compared to the other instruments of the orchestra, are as a cannon compared to a gun."

“[...] l'on vit entrer sur la scène les bandes militaires, et enfin les grands instrumens de Sax, qui sont aux autres voix de l'horchestre [sic] comme une pièce de canon est à un fusil." ${ }^{\text {II }}$

The most intriguing question, however, is why Berlioz did not use the saxophone. Apart from the famous Hymne sacré, the score of which is lost, and which, by the way, is scored for trompette Sax, saxhorn, clarinette basse and saxophone basse. Berlioz wrote nothing for the instrument. As a matter of fact, he left open staves for an alto and a tenor saxophone in La Damnation de Faust, but they remained blank. Since he was an ardent supporter of Sax's new families of musical instruments, why did Berlioz not write a single note for saxophones - an instrument whose merits he praised on several occasions ?32 $^{32}$ On the occasion of a concert by the orientalist Soualle in Paris in I851, Berlioz gives the following reason for not using them: 33

31 See Hector Berlioz: Feuilleton. Académie impériale de musique, in: Journal des débats politiques et littéraires, 6 February I853, pp. [I]f., here p. [II].

In the Feuilleton of Le Journal des débats of 2I August I849, p. [II], Berlioz describes the saxophone's sound qualities as follows: "La voix du saxophone, dont la famille comprend sept individus de tailles différentes, tient le milieu entre la voix des instrumens de cuivre et celle des instrumens de bois; elle participe aussi, mais avec beaucoup plus de puissance, de la sonorité des instrumens à archet. Son principal mérite, selon moi, est dans la beauté variée de son accent; tantôt grave et calme, tantôt passionné, tantôt rêveur, ou mélancolique, ou vague, comme l'écho affaibli d'un écho, comme les plaintes indistinctes de la brise dans les bois, et mieux encore, comme les vibrations mystérieuses d'une cloche, longtemps après qu'elle a été frappée. Aucun autre instrument de musique existant, à moi connu, ne possède cette curieuse sonorité placée sur la limite du silence. [...] Mais on n'a encore rien composé pour cette voix nouvelle [...]." - "The sound of the saxophone, a family consisting of seven individuals of different sizes, is midway between the sound of the brass and that of the woodwind instruments; it also shares, though with much more power, the sonority of bowed [string] instruments. Its main merit, in my opinion, is its capacity to vary its character. Sometimes it is serious and quiet, at other times passionate, sometimes dreamy, melancholy or vague, as the faint echo of an echo, like the indistinct wail of a breeze in the woods, and even better, as the mysterious vibrations of a bell, long after it was hit. No other extant musical instrument known to me has this strange sound that emerges on the edge of silence [...]. But nothing has as yet been composed for this new voice [...]." Robert Howe, partly relying on Peter Bloom's The Cambridge Companion to Berlioz (Cambridge 200o) and Jacques Barzun's Berlioz and His Century (Chicago I956), gives external causes for Berlioz's reluctance to use saxophones: (a) the Parisian musical public being deaf to Berlioz's works, (b) his travelling abroad, and (c) the difficult politics at the Paris Opéra. See Robert Howe: The Invention and Early Development of the Saxophone, in: Journal of the American Musical Instrument Society 29 (2003), pp. 97- 
"Mr. Soualle returned recently from London and produced a great sensation by playing Sax's masterpiece, the saxophone, for the first time here in Paris, showing off all its advantages. This instrument has incomparable expressive qualities; the accuracy and beauty of the sound it produces when handled by somebody who has the technique for playing it is such that it may challenge, in slow movements, the most skilled singers. This instrument cries, sighs, dreams, it has a crescendo and is able to soften its voice gradually until it is the echo of an echo of an echo, finally becoming the sounds of twilight. In a few years, when the use of the saxophone will be widespread among performers, this wonderful 'organ' will enable composers to produce effects that we cannot imagine today."

“[...] M. Soualle, qui, récemment revenu de Londres, a produit une grande sensation en faisant entendre pour la première fois à Paris, avec tous ses avantages, le saxophone, chef-d'œuvre de Sax. Cet instrument a des qualités expressives, incomparables; la justesse et la beauté des sons qu'il produit quand on en possède bien le mécanisme sont telles qu'il peut, dans des morceaux lents, défier les plus habiles chanteurs. Il pleure, il soupire, il rêve; il possède le crescendo, il peut affaiblir graduellement sa voix jusqu'à l'écho de l'écho de l'écho, jusqu'au son crépusculaire. Dans quelques années, quand l'usage du saxophone se sera répandu parmi les exécutans, les compositeurs pourront, au moyen de cet admirable organe, produire des effets dont on n'a pas d'idée en ce moment."34

What Berlioz says here is: I adore the saxophone, but we will have to wait for more skilled musicians before composers will be able to use it. In his treatises on orchestration, Berlioz offered a rather authoritarian vision of the tone qualities he wanted for the different instruments of the orchestra, categorically rejecting those instruments that were unable to produce a homogeneous timbre over their entire compass. 35 In his review of Soualle and the saxophone, Berlioz seems to distrust not the man, but the distinctive tone quality produced by each individual player. That is exactly what in another, more positive context, has been considered to be the advantage of the saxophone:

“In fact the saxophone doesn't really have much of a 'core' sound. It merely responds to the way you blow it. This is what makes living close to a saxophone beginner such a character-building experience. However, once a building player learns to control the instrument reasonably well this apparent limitation turns out to be a most precious quality. It means that you can imagine the sound you want to make and, with time, practice and a modicum of talent, it will emerge."36

I80, here p.II5 (footnote 45). Although arguments regarding social constraints are generally valid, one cannot imagine Berlioz simply acquiescing to purely social or political circumstances. For example, his opera Les Tropens was never produced on stage complete in his lifetime, but this work perfectly reflects Berlioz's aesthetic programme. As a consequence, it seems to be more appropriate to this author to consider the reasons arising from Berlioz's own aesthetic.

34 See Hector Berlioz: Feuilleton, in: Journal des débats politiques et littéraires, I3 April I85I, pp. [I]f., here p. [II].

35 See Ignace De Keyser: Les instruments de musique jugés par Hector Berlioz in: Berlioz. Homme de lettres, ed. by Georges Zaragoza, Neuilly-les-Dijon 2006, pp. I3I-I55.

36 See Dave Gelly: Jazz saxophone, in: Brian Priestly/Dave Gelly/Paul Trynka/Tony Bacon: The Sax \& Brass Book. Saxophones, Trumpets and Trombones in Jazz, Rock and Pop, London 1998, Paperback edition San Francisco 2003, pp.30-69, here p. 44. 
There is a second reason. Berlioz only heard the saxophone in its earliest stage, namely a bass saxophone or "ophicleide-à-bec" as he called it. If he had known, for example, Singelée's Solo de concert No.7, op. 93 (I863) for baritone saxophone - the virtuosity of which is simply astonishing - he would perhaps have drawn different conclusions.

The third reason for Berlioz not having used saxophones, is their orchestral concept. According to Sax, the saxophones constitute an entire, distinct instrument family. As a consequence, the concept of a saxophone family is here in competition with the string family as found in the Romantic symphony orchestra. As an excellent orchestrator, Berlioz would surely never have preferred a set of saxophones instead of the strings in a symphony orchestra. To use the saxophone orchestra as a full orchestra would have been a draconian measure, even for a progressive composer such as Berlioz.

The Distins The Distins acknowledged this specifically orchestral concept of the saxhorns: they played and promoted a saxhorn ensemble in Britain and even in the us. According to Eugenia Mitroulia and Arnold Myers, "it is believed that they were so influential there that they were responsible for the popularisation of the term 'saxhorn', which later was associated with the over-the-shoulder instruments that became known as 'over-the-shoulder-sax-horns.'"37

The collaboration with Sax that had started in I844, when Distin became Sax's commercial agent in Britain, came to an end in I85I. Just like some of Sax's competitors in France, the Distins integrated Sax instruments into their own production. I845 they registered saxhorns in Britain - a lower form of protection than a genuine patent. That was completely legal, since patent protection at that time was limited to the country in which the patent had been registered. Incidentally, the design of these "registered saxhorns" only shows a four-valve contralto saxhorn equipped with Berlin valves. In February I85I the Distins announced the use of their "newly invented euphonic horns". The fact that they were making their own instruments might have contravened their contract with Sax. After revoking their contract with Sax, "the Distins' main preoccupation was the improvement of brass instruments, but two of their patents were related to percussion instruments and one of the three registered designs was for 'an improved clarionet'."38 Unlike Sax, the Distins developed a commercially successful musical instrument business; Henry Distin sold it to Boosey \& Company in I868.

Eugenia Mitroulia/Arnold Myers: The Distin Family as Instrument Makers and Dealers, in: Scottish Music Review 2 (20II), No.I, p.4, http://citeseerx.ist.psu.edu/viewdoc/download?doi=Io.I.I.849.4I75\& rep=repi\&type $=p d f(22$. June 2or8). 
Critical discourse We have already referred to the intellectuals who supported Sax's case (see above), but what were the negative critical voices? The best-known of them is the letter of protest of 1845 , signed by 34 French wind instrument makers, which has often been quoted:

"By introducing the monopoly of Sax [...], the Commission has at the same time claimed for itself the incredible mission of setting limits on art. Any further progress will be paralysed, any improvement will become impossible. If that is the goal that is being proposed, then no doubt success is assured.

[The instruments of our system] are good and leave nothing to be desired: no one has ever thought to complain. The musical instrument manufactory has made tremendous progress. Further developments are made every year, and the army has benefitted from this in every respect."

"En introduisant le monopole Sax [...], la Commission s'arroge en même temps l'incroyable mission de fixer des limites à l'art. Tout progrès ultérieur sera paralysé, toute amélioration deviendra impossible. Si tel est le but qu'on se propose, on réussira infailliblement.

[Les instruments de notre système] sont bons et ne laissent rien à désirer: nul n'a jamais songé à s'en plaindre; la facture a fait des progrès immenses, qui se sont développés annuellement, et dont l'armée a, sur tous les points, ressenti les bienfaits." ${ }^{39}$

This letter of protest reflects the fear of unfair competition on the part of Sax's colleagues. However, it also reflects a remarkable, conflicting discourse with regard to the question of progress. Although the signatories invoke the idea of progress, they pay lip service to an ideology that is not their own. From our point of view, Sax's competitors were conservative. What they really wanted to do was to produce fine instruments of high quality, of which they could be proud. The idea of making revolutionary, new musical instruments was beyond them. As late as 1867, the same refrain comes back again:

"We note that the jury did not take into account the proper or improper making of musical instruments, but mostly paid attention to the accuracy of tone and the quality of sound. It is true that both qualities are essential. However, would it not be possible to recognise the degree of perfection attained by every maker in the manufacture of their products? Some of them excel in fine and elegant work, while others are noticed for the reliability of their instruments.

We know that the members of the jury are not competent to judge the industrial aspects of the instruments on display in the Exhibition. Why not include craftsmen in their committees who might help to make their analysis more substantial and more comprehensive? We notice this gap, since we know that manufactories whose production is far superior to that of their competitors are nevertheless awarded with the same rank by the jury."

"Nous ferons observer que le jury n'a pas tenu compte de la bonne ou de la mauvaise construction des instruments, ce qui attire le plus son attention c'est la justesse et la sonorité; il est vrai que c'est l'essentiel, mais ne serait-il pas possible de reconnaître le degré de perfection que chaque fabricant

39 See Protestation de tous les facteurs d'instruments de musique militaire de France, adressée à Monsieur le Ministre de la Guerre, sur la commission nommée pour l'examen de nouveaux instruments, first published by Malou Haine: Adolphe Sax, p. I77. 
apporte dans la fabrication de ses produits? Tel d'entre eux brille par le soin et l'élégance, tel autre se fait remarquer par la solidité de ses instruments.

Nous savons que MM. les membres du Jury ne sont pas compétents pour juger de la partie industrielle des instruments exposés; ne pourrait-on pas alors les adjoindre des hommes du métier qui rendraient leur examen plus sûr et plus complet? Si nous signalons cette lacune, c'est que nous savons que des maisons dont le travail est bien supérieur à d'autres se trouvent classées au même rang par le Jury des récompenses." 40

As we have seen, Sax's military networks allowed him to survive the I848 Revolution, and they helped him to become accepted after the establishment of the Second Empire, under Napoleon III. But why was he ruined afterwards, when the Second Empire was abolished and the Third Republic declared? Was this only because he lacked the necessary political networks and support?

In 1877 , Sax went bankrupt for the third time, but more importantly, his sales and consequently his production declined dramatically after I870. In that same period, Gautrot and Thibouville-Lamy embarked on mass production at low retail prices. Comettant - a loyal supporter of Sax's case - quoted a certain Lacome who claimed that Gautrot preferred to produce on a large scale and at very low prices rather than produce instruments of good quality that were well-tuned and solidly made. ${ }^{4 \mathrm{I}}$ A year after Sax's death, Auguste Tolbecque (I830-I9I9), a solo cello player of Belgian origin at the Paris Société des concerts $d u$ Conservatoire, provided complementary information about ThibouvilleLamy in a letter to Victor Mahillon (I84I-I924), the first curator of the Brussels MIM. Tolbecque compared Sax to Thibouville-Lamy in the following terms:

"In Paris where I lived at that time, I could follow a part of this hero's [Sax's] life; [...] despite the honours that were awarded to him, I find that this poor devil was roughly shackled by the jealousy of his competitors; when I compare his life of labour and the intellectual energy of this martyr of talent and genius with the life of glory and wellbeing that hawkers like Thibouville Lamy!!! enjoy, my hair (the little that I have left) stands on end and I would almost like to bite someone.

The one knew misery and sorrow, trouble of all kinds, and bankruptcy at the end, and was exploited on all sides, copied and counterfeited. The other has an excellent shop where everything is rubbish, violins embossed, articles from Germany, rosin at two pennies the piece, instruments built in La Couture and Mirecourt against all common sense. But he is president of every committee, decorated, an officer and a millionaire. The potentate at whose feet most instrument makers submit. I must be dreaming!"

“J'ai pu suivre à Paris où j'étais une partie de la vie du héros, et [...] je trouve que malgré les honneurs qui lui ont été décernés, ce pauvre Diable a été rudement étrié [sic] par la jalousie de ses concurrents

See Rapport adressé à la commission d'encouragement par les délégations des facteurs d'instruments de musique en cuivre et en bois, in: Exposition Universelle de Paris I867, Rapports des délégations ouvrières, ed. by Arnould Desvernay, Vol. I, Paris [1867], p. I.

41 See Oscar Commettant: La musique, les musiciens et les instruments de musique chez les différents peuples du monde, Paris I869, pp.7IIf. 
et quand je compare la vie de labeur, la dépense cérébrale de ce martyr de talent et du génie, à la vie toute de gloire, de bien être des camelotteurs du genre de Thibouville Lamy!!! mes cheveux (le peu qui m'en reste) se dressent et j'ai presque envie de mordre.

A l'un misère et chagrin, ennuis de toutes sortes, faillite terminale, exploité par les uns et par les autres, copié, contrefait. A l'autre, excellente boutique où tout est camelote, violons gaufrés, articles d'Allemagne, colophane à 2 sous le morceau, instruments de La Couture et de Mirecourt construits en dépit du sens commun; Mais Président de toutes les commissions, décoré, officier, millionnaire. Le potentat aux pieds duquel la plus grande partie des facteurs font leur soumission. Je crois rêver!"42

Apparently, Sax production was embedded in a different logic and perhaps he too much relied on his networks, neglecting the merciless laws of the musical instrument market.

Sax's canon What, indeed, was Sax's canon? It has in part been described by Malou Haine and the present author, ${ }^{43}$ and has been well formulated by Eugenia Mitroulia and Arnold Meyers:

"The uniformity and regularity of the saxhorn group and the pedagogical advantages in their use, such as the same treble-clef notation and the same fingering, should definitely be ascribed to him." 44

This combination of an organological entity, a pedagogical concern and an orchestral concept is valid not only for Sax's brasswind instruments, for the same is of course true of saxophones. Sax's concept of family-building for groups of musical instruments represents an "idée fixe" that can be traced not only through his patents but also in his activities as a band director and concert organiser. The I843 "saxhorn" and the I845 "saxotromba" patents provide initial evidence of Sax's concept of family-building with regard to musical instruments. Later innovations, such as the 1846 saxophone patent, the I852 saxtuba patent and the I852/I859 patents for the "nouveaux saxhorns", merely confirm how Sax strived to realise his initial concept. Moreover, Sax's ideas on family-building in musical instruments were not restricted to brasswind instruments. In I847, Berlioz wrote of a project by Sax to rebuild the family of stringed musical instruments:

"In order to provide the very large symphony orchestras with all possible resources and a fullness of sound, A. Sax proposes to join to the various families of wind instruments a large family of bowed stringed instruments. These would consist of violins in different registers, such as suraigus, sopranos, tenors, altos, baritones, basses, and double basses in different sizes and pitch. That means that the current non-transposing violin in $\mathrm{C}$ would be replaced by other violins of higher and lower registers

42 Letter from Auguste Tolbecque to Victor Mahillon, dated 2 December I895 [Brussels, Mim, Mahillon Archives - Dossier Tolbecque].

43 See Malou Haine/Ignace De Keyser: Instruments Sax/Saxinstrumenten/Sax Instruments, Liège 200o, Reprint Brussels 2013; idem: Adolphe Sax et la diffusion de ses nouveaux instruments, in: Cahiers Rémois de Musicologie 6 (December 20II), pp. 87-I24.

44 See Eugenia Mitroulia/Arnold Myers: Adolphe Sax. Visionary or Plagiarist?, in: Historic Brass Societp Journal 20 (2008), pp. 93-I4I, here p. I35. 
in the nomenclature that I have just mentioned, but still tuned in fifths. However, they would become transposing violins in $\mathrm{F}$, in $\mathrm{G}$, in $\mathrm{E} b$ and in $\mathrm{B}$, just like wind instruments. By increasing their range, especially in the lower registers, and through the effect of the intersection of their open strings, they would give to this instrumental mass a much greater sound."

"A. Sax propose, afin de donner à un très grand orchestre symphonique toutes les ressources et toute la sonorité possibles, de réunir aux diverses familles d'instrumens à vent une famille nombreuse d'instrumens à cordes, à archet, composée de violons suraigus, soprani, ténors, altos, barytons, basses et contrebasses de diverses dimensions et dans différens tons. C'est-à-dire qu'en supposant le violon actuel non transpositeur en $u t$, il y aurait d'autres violons plus aigus et plus graves sous les diverses dénominations que je viens d'indiquer, qui, accordés toujours par quintes cependant, deviendraient des violons transpositeurs en fa, en sol, en mi bémol, en si naturel, comme les instrumens à vent, et, tout en augmentant l'étendue de l'échelle, au grave surtout, donneraient par l'entrecroisement des cordes à vide une beaucoup plus grande sonorité à la masse instrumentale." 45

It is likely that Sax's “idée fixe" of family-building for musical instruments was influenced by Fétis ${ }^{46}$ or Wieprecht, ${ }^{47}$ though it is difficult to prove. As a musicologist, Fétis could have been aware of the consort principle of Renaissance music. However, there is no evidence of such a link in his writings. In I84I, Fétis indeed welcomed the bass, double bass and "bourdon" clarinets, patented by Adolphe Sax in I838, as an opportunity to build a complete family or "a complete system of clarinets" as he called it, "now that a search for variety in instrumentation is occupying many composers". ${ }^{4}$

On the other hand, before leaving Brussels and settling in Paris, Sax had travelled to Berlin where he became acquainted with German brasswind instrument making 49 probably with Wieprecht's family of cornets in particular (I833-I835)..$^{\circ}$ Either way, building a family comprising an organological entity as both a pedagogical concern and an orchestral concept was something unique to Sax's oeuvre.

There is a fourth aspect to this: the use of his family name to designate this combination of an organological entity, a pedagogical method and an orchestral concept. For

45 See Hector Berlioz: Feuilleton. Nouvelle Salle de concerts d'Ad. Sax, in: Journal des débats politiques et littéraires, I4 February I847, pp. [I]f., here p. [II].

46 "Drawing on the example of Renaissance consorts, the musicologist Fétis called for families of like instruments extending from bass to piccolo range, which began a vogue in the r83os." See Howe: The Invention and Early Development of the Saxophone, p. I5I.

47 See Sabine K. Klaus's article in the present volume, pp. 97-Iı2.

48 "Dans un temps où la recherche des variétés dans les effets de l'instrumentation préoccupe beaucoup de compositeurs, le système complet de la sonorité de la clarinette n'est pas sans importance, [...] il a la petite clarinette en mi bémol, la clarinette en si bémol divisée en première et seconde, la clarinette alto, la clarinette basse et la clarinette contre-basse." See François-Joseph Fétis: Nouvelles clarinettes de M. Sax fils (Suite et fin), in: Revue et gazette musicale de Paris, Io January I84I, pp. I9f., here p. 20.

49 Haine: Sax, p.57.

50 Herbert Heyde: Das Ventilblasinstrument. Seine Entwicklung im deutschsprachigen Raum von den Anfängen bis zur Gegenwart, Wiesbaden I987, pp. 204-206. 
the saxophone, there is enough evidence that Sax used his own name to designate what Berlioz rightly called an "ophicléide-à-bec" when it first appeared on the Paris concert scene. For the saxhorns, things are not so clear: the 1843 patent does not mention any saxhorn. It was perhaps Georges Kastner who called the new instruments thus. The list of 53 neologisms used to designate musical instruments with the name of the inventor in Table 6 makes clear that Sax set the tone - in other words, that he established a new canon.

\section{Conclusions}

I. Musical competitions, networks, a critical discourse and a "canon" of instruments significantly contributed to the perception of Sax as a "genius" by his contemporaries and to his creation of the aura of a genius around himself - not unlike the example of Beethoven among composers.

2. Sax's networks among French and international music professionals, the French army establishment and political elite, writers, artists and scientists considerably helped him in his career in Paris as an inventor and maker of new musical instruments - just as had been the case in Brussels with his father Charles-Joseph.

3. Sax's political networks were no longer of any use with the establishment of the Third French Republic after the I87o Paris Commune. The falling away of this important support, together with Sax's inability to shift to more market-oriented production, caused his third and final bankruptcy. At the same time, more commercially oriented makers such as Gautrot and Thibouville-Lamy emerged, who enjoyed success.

4. Sax's most long-lasting, loyal supporters were the music professionals. Initially these were renowned composers of the day, but subsequently they included a broad range of composers, virtuosos and bandleaders whose influence in musical life was much greater than has hitherto been supposed. However, more research is needed on this topic.

5. Some music professionals changed sides. Berlioz's concept of orchestration did not match with that of Sax, while the Distins broke with Sax for purely pragmatic reasons, preferring to set up their own business.

6. In his last period - after the I870 Commune - Sax's supporters among these music professionals were mostly opera composers. Their support coincided with Sax's greater involvement in the direction of the Opéra banda in his final years.

7. Sax's canon consists of instruments named after him, with new or renewed organological entities, a pedagogical "road map", and an orchestral concept. During his lifetime, Sax was able to impose his musical canon (a) directly through the army, through teaching military musicians, through his activities with his own Fanfare and Harmonie ensembles, and in the Opéra banda; and (b) indirectly through the 
actions of musicians and makers such as the Distins, and through his music publishing fund.

8. However, Sax's patrons in the army establishment and the political elite only partly succeeded in pushing through his ideas - essentially as a consequence of the political earthquakes of the time. During the July Monarchy (Louis-Philippe) and the Second Empire (Napoléon III), Sax's instruments were imposed on the army bands and withdrawn after a period of just a few years.

9. One unexpected result of Sax's canon can be found in the durability of neologisms for new instruments based on the name of their inventor. Sax was one of the first inventors to name instruments in this fashion, and was certainly the most successful. Everyone knows the saxophones. On the other hand, sarrusophones and rothphones are known only to organologists - not to mention bimboniphones, müllerphones and even the termenvoksa, the last of one perhaps being the most innovative musical instrument ever invented. If Sax had called his saxhorns "newly invented euphonic horns", as did the Distins in I859, perhaps no one would even remember them. 


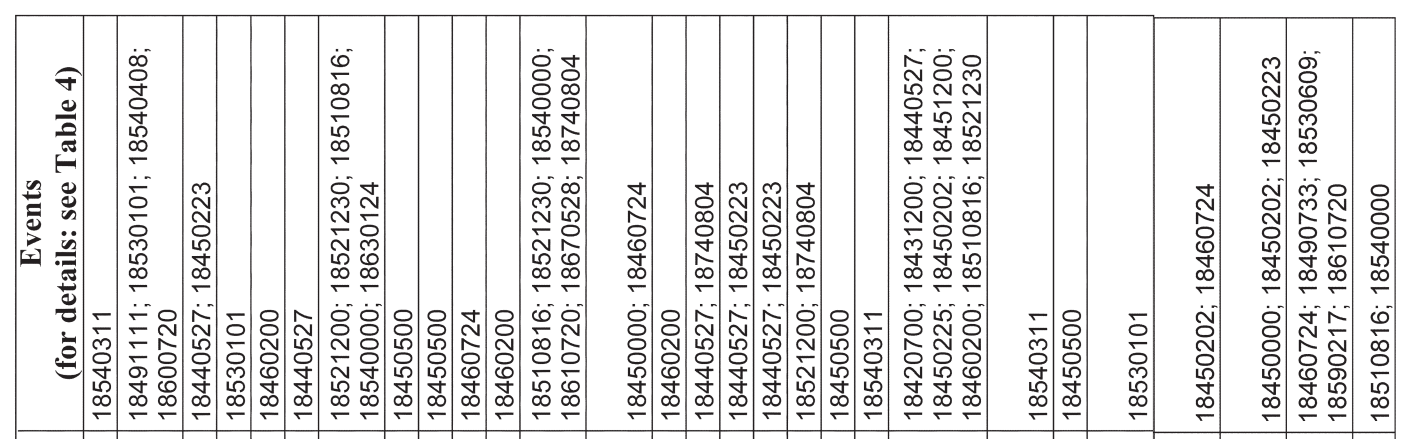

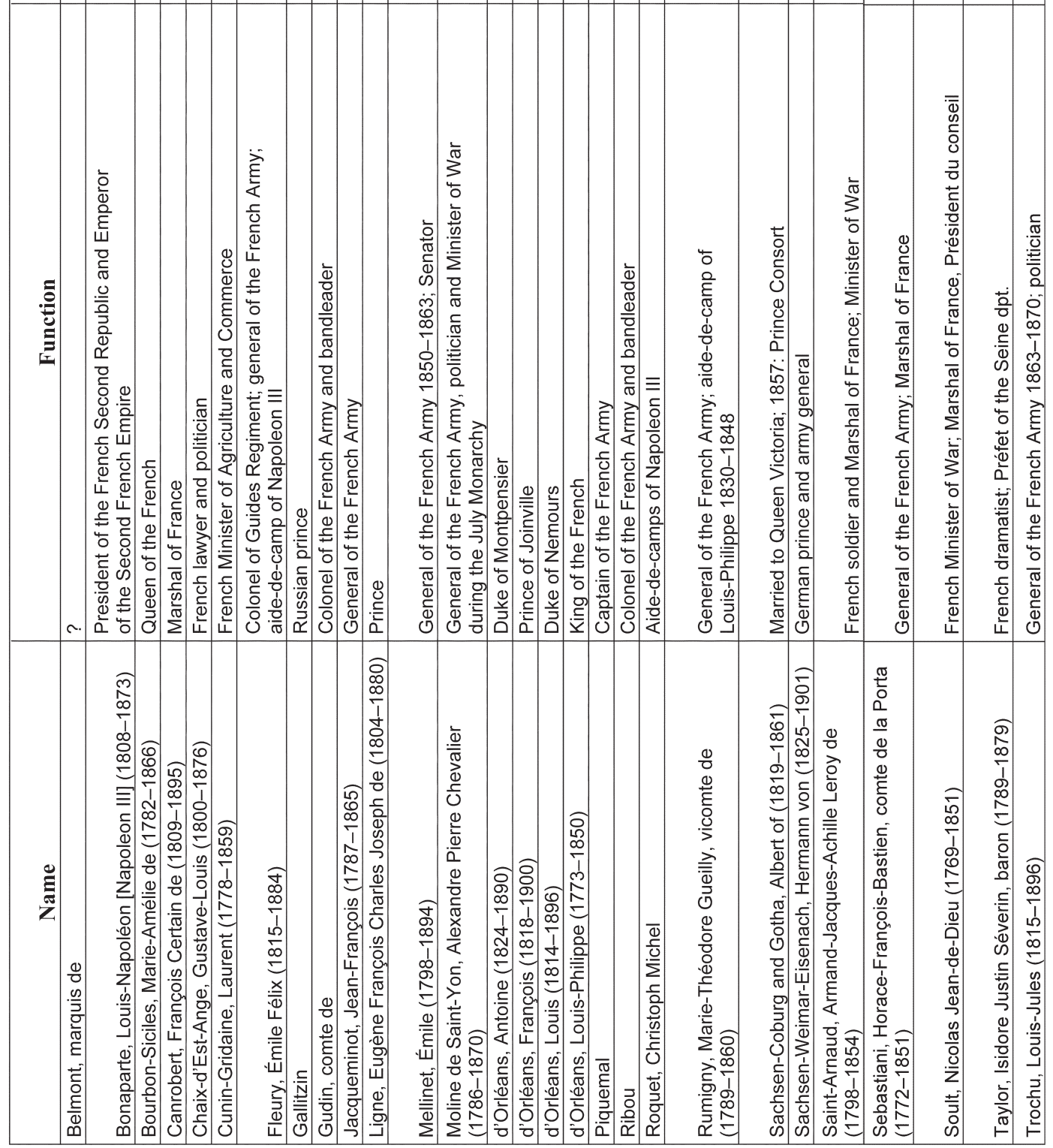

TAB LE 1 Sax's networks among politicians and the army establishment 


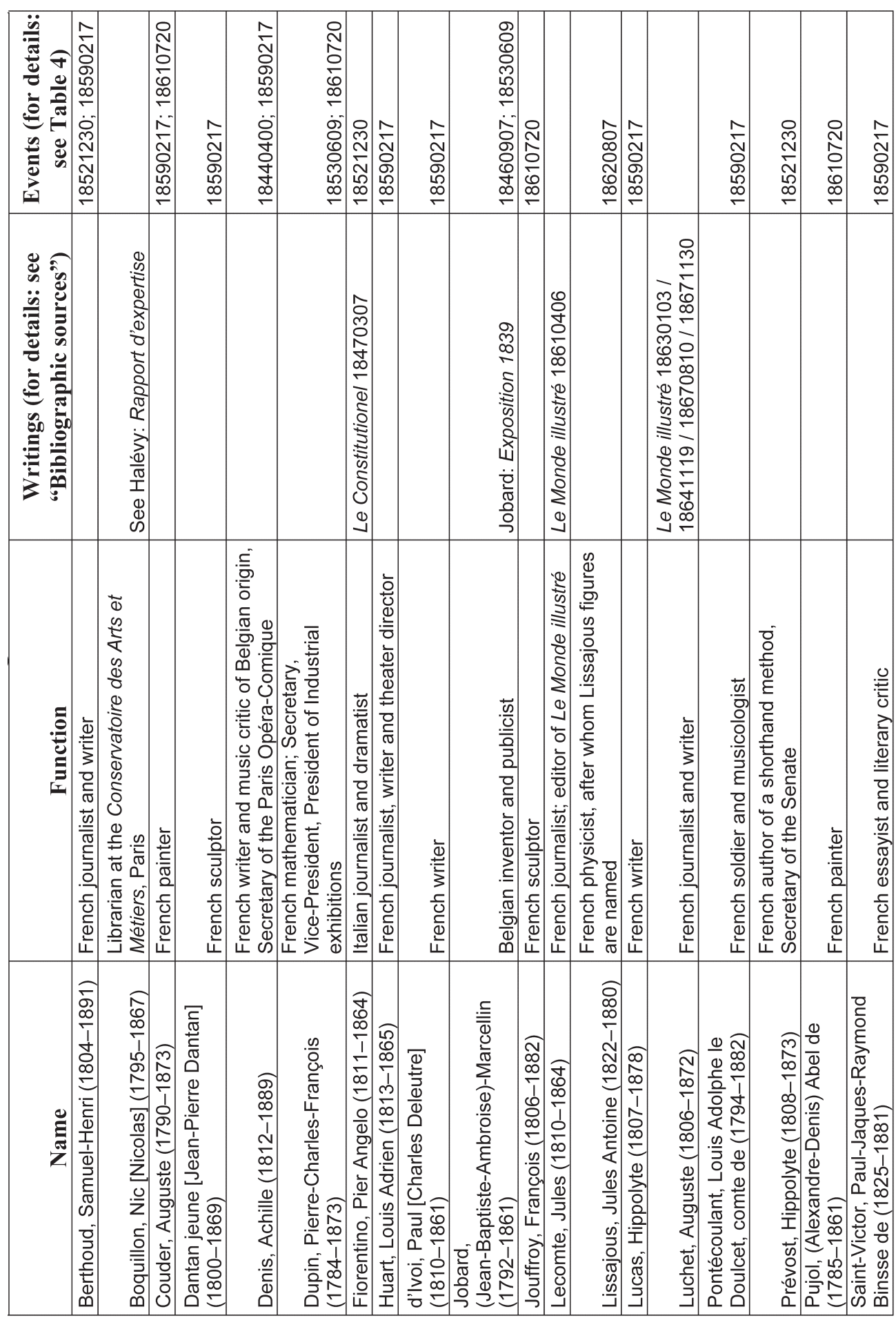

TAB LE 2 Sax's networks among writers, artists and scientists 


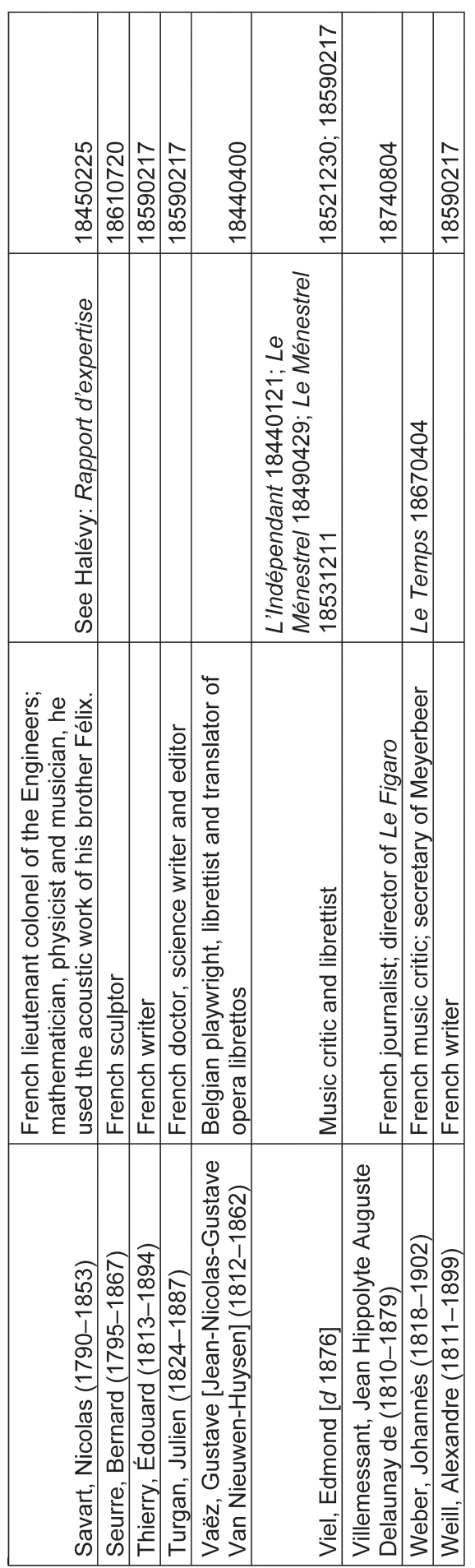




\begin{tabular}{|c|c|c|c|c|c|c|c|c|c|c|c|c|c|c|}
\hline 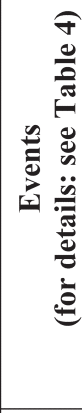 & 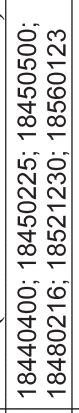 & 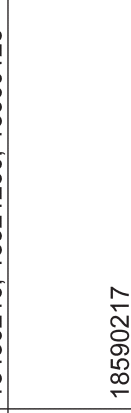 & 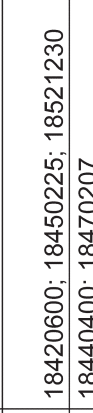 & 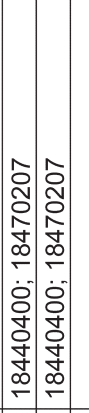 & & 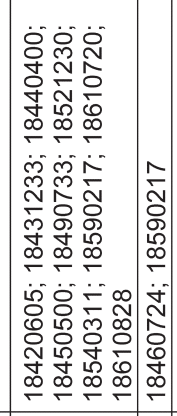 & & & 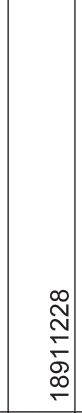 & 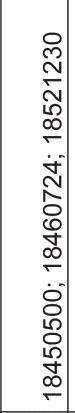 & 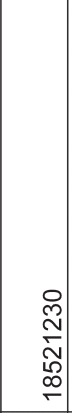 & & & 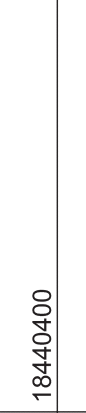 \\
\hline 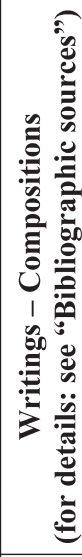 & & 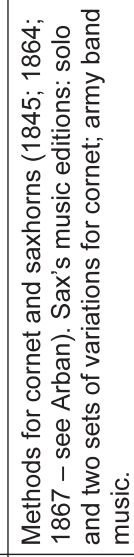 & & & 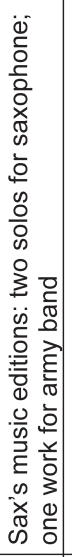 & 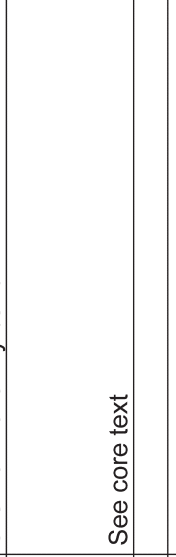 & 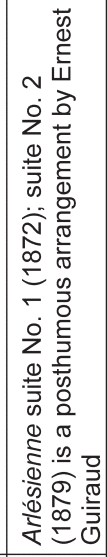 & 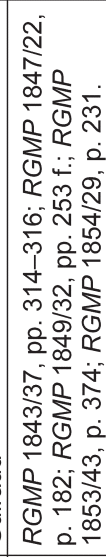 & & 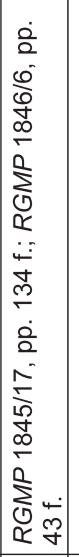 & & & & 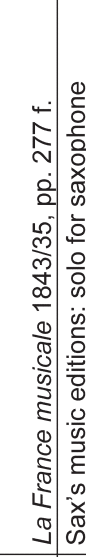 \\
\hline 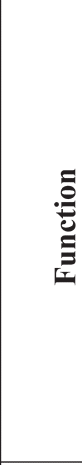 & 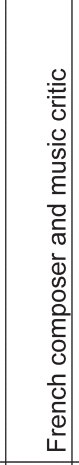 & 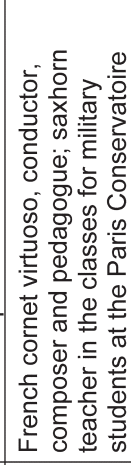 & 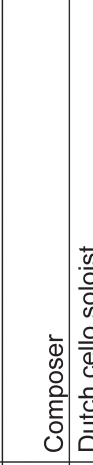 & 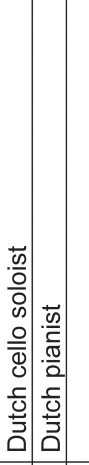 & 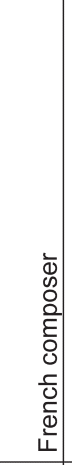 & 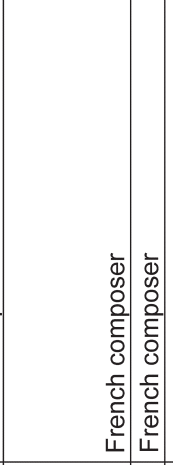 & $\begin{array}{l}\bar{\Phi} \\
0 \\
0 \\
0 \\
0 \\
0 \\
\frac{\tau}{0}\end{array}$ & 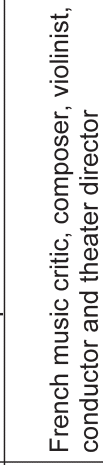 & 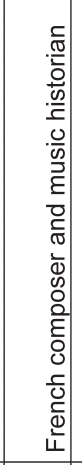 & 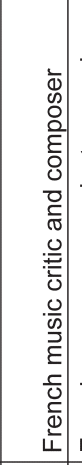 & 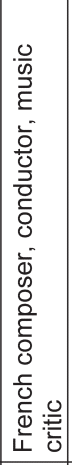 & 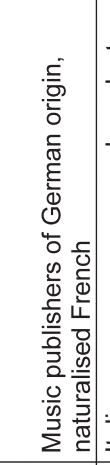 & 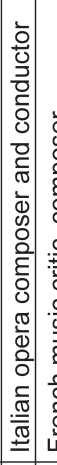 & 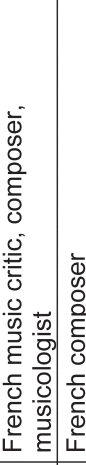 \\
\hline 2 & 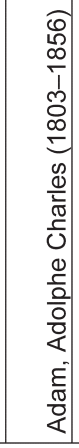 & 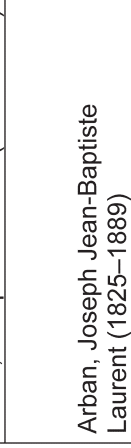 & 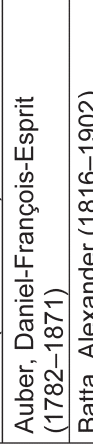 & 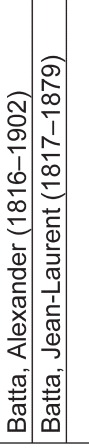 & 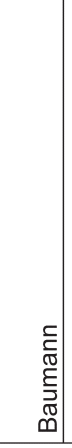 & 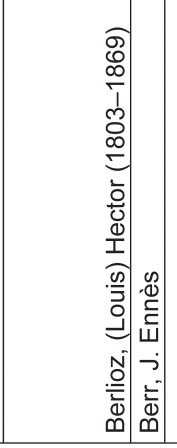 & 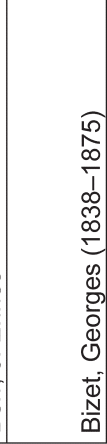 & 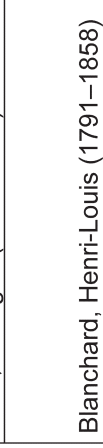 & 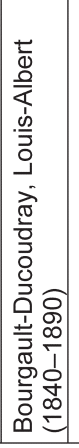 & 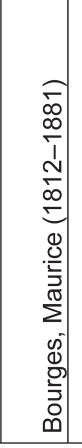 & 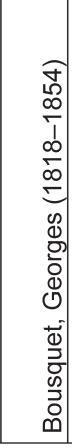 & 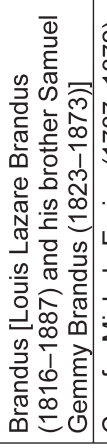 & 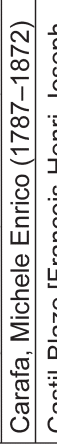 & 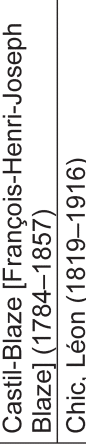 \\
\hline
\end{tabular}

TABLE 3 Sax's networks among music professionals 


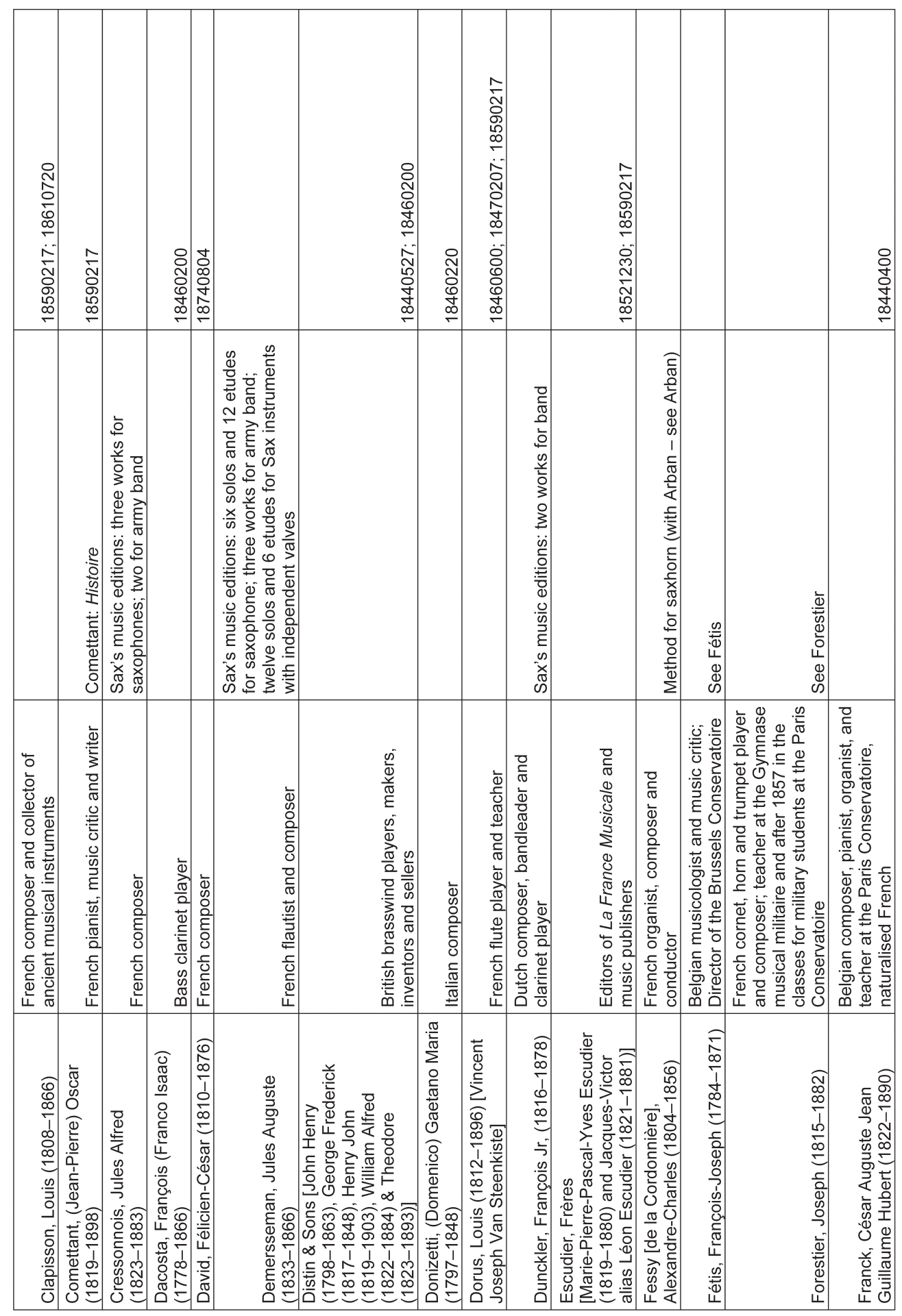




\begin{tabular}{|c|c|c|c|c|c|c|c|c|c|c|c|c|c|}
\hline 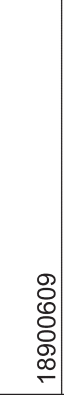 & 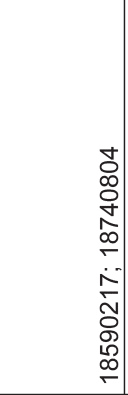 & 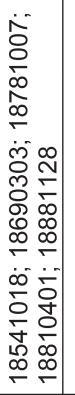 & & 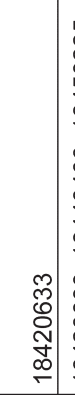 & 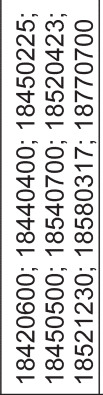 & $\begin{array}{l}\stackrel{0}{N} \\
\underset{N}{N} \\
\stackrel{\infty}{\infty} \\
\stackrel{\infty}{-}\end{array}$ & 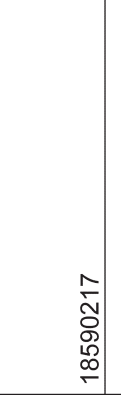 & $\begin{array}{l}\mathfrak{N} \\
\text { D. } \\
0 \\
\infty \\
0\end{array}$ & 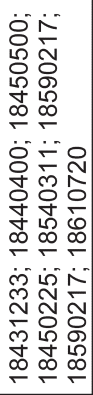 & 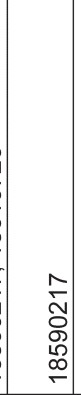 & & 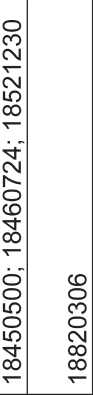 & 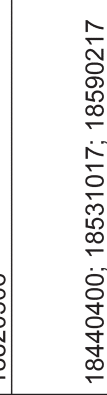 \\
\hline 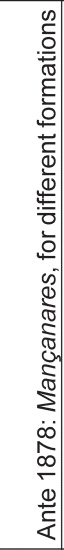 & & & 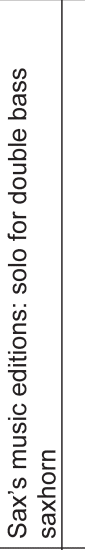 & & 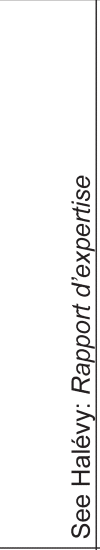 & & 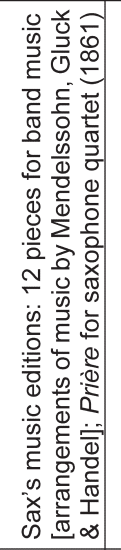 & & 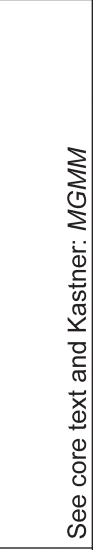 & 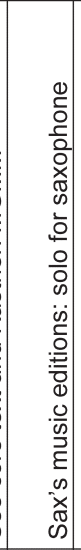 & 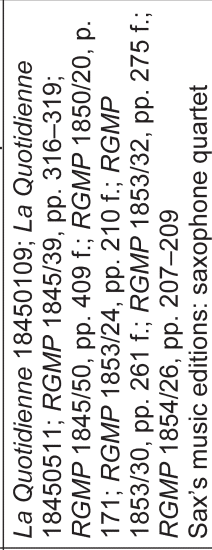 & 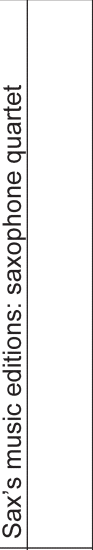 & \\
\hline 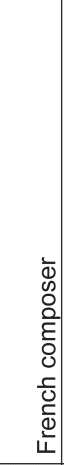 & 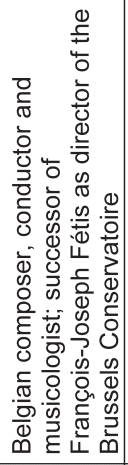 & 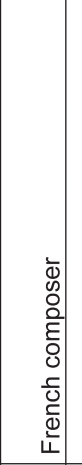 & 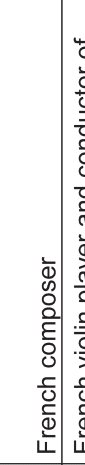 & 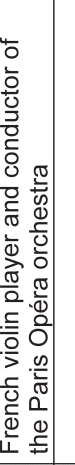 & 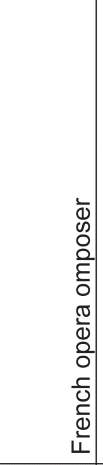 & 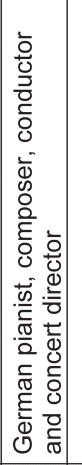 & 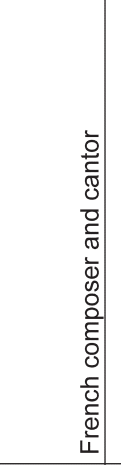 & 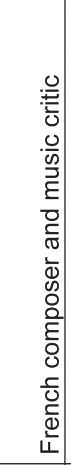 & 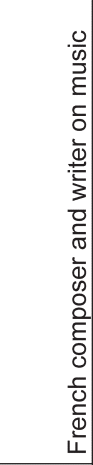 & 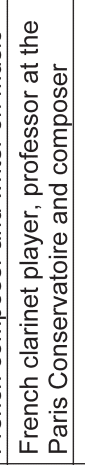 & & 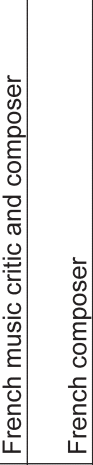 & 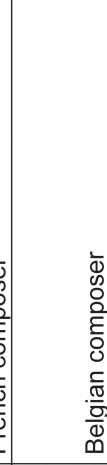 \\
\hline 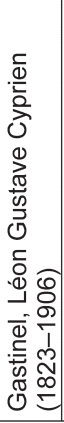 & 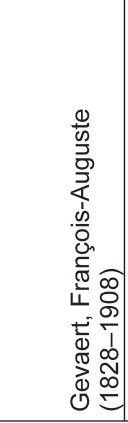 & 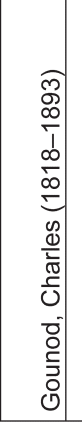 & 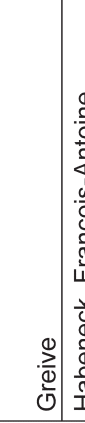 & 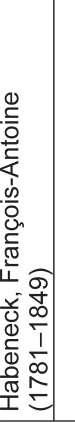 & 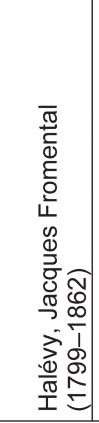 & 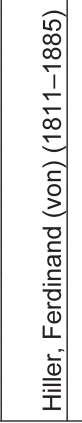 & 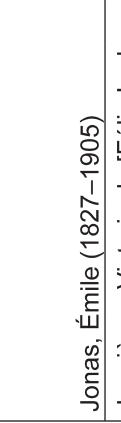 & 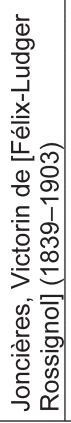 & 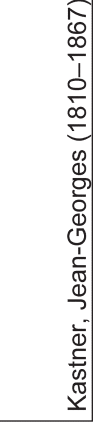 & 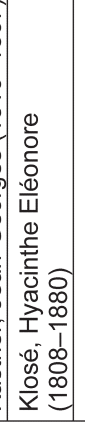 & 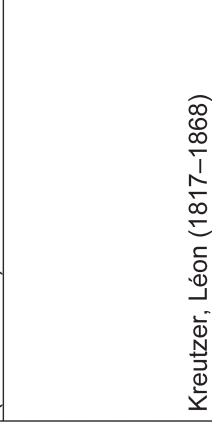 & 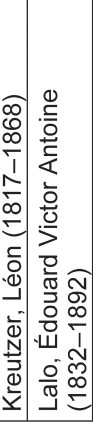 & 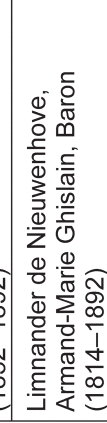 \\
\hline
\end{tabular}




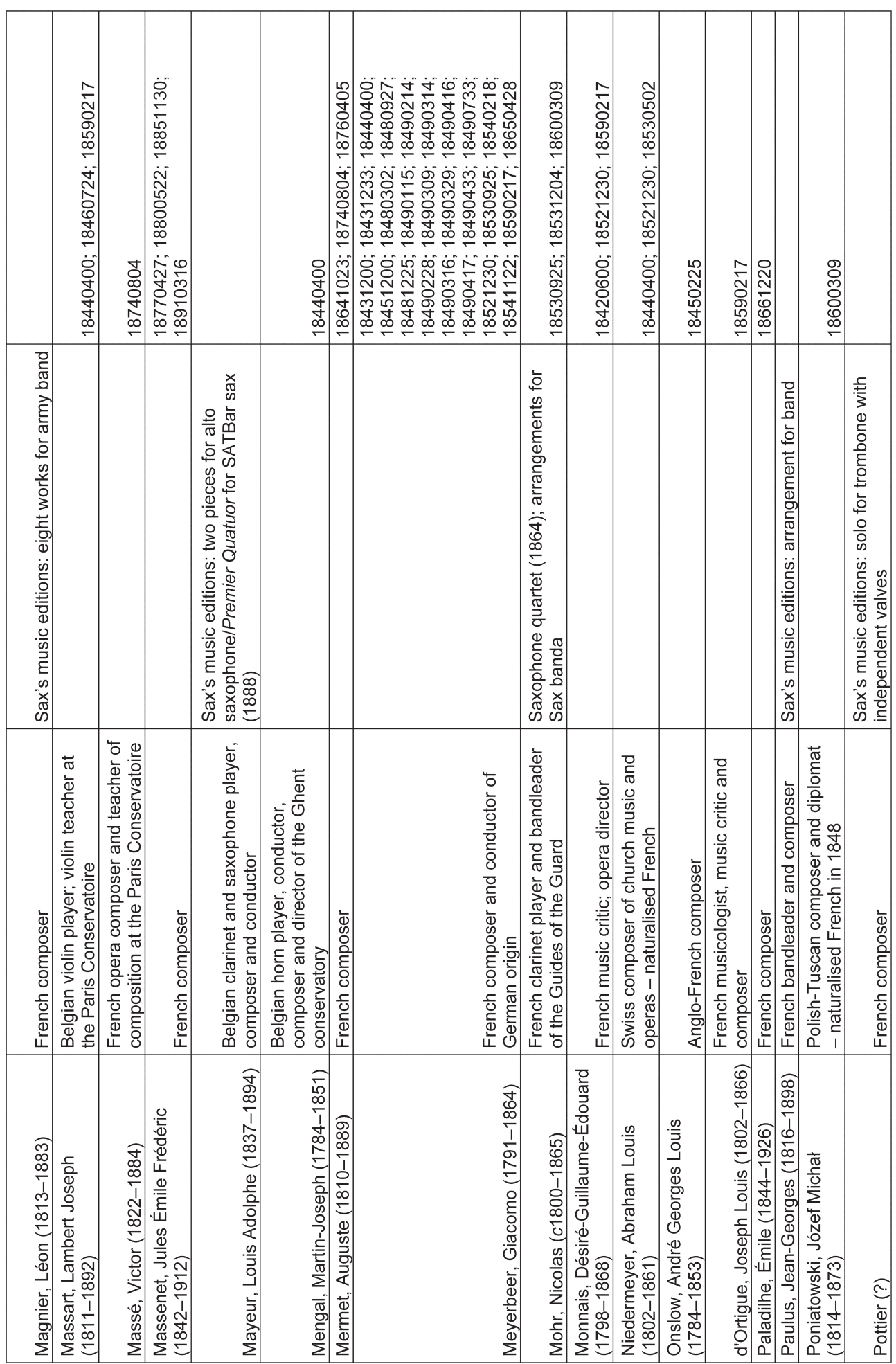




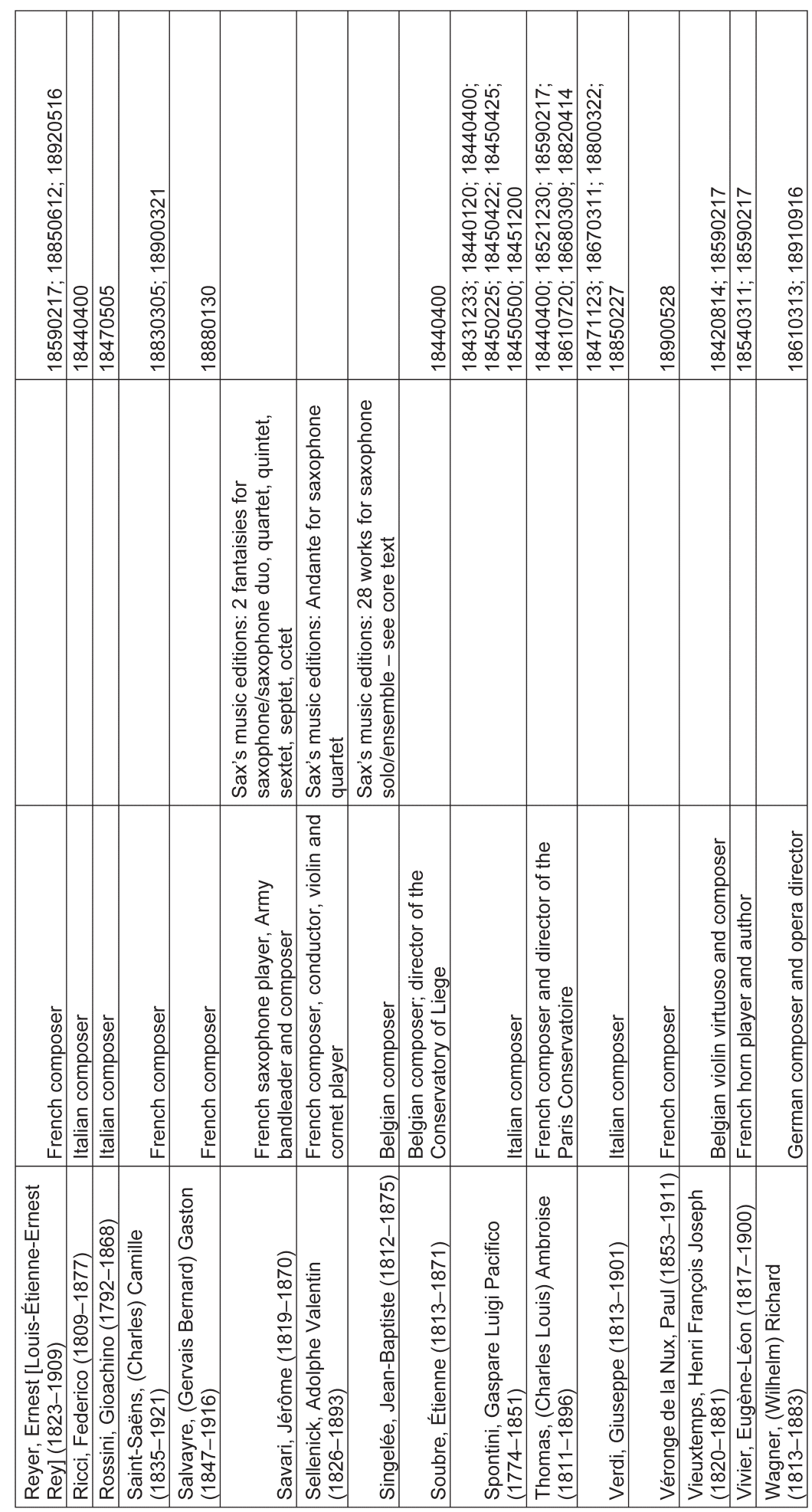




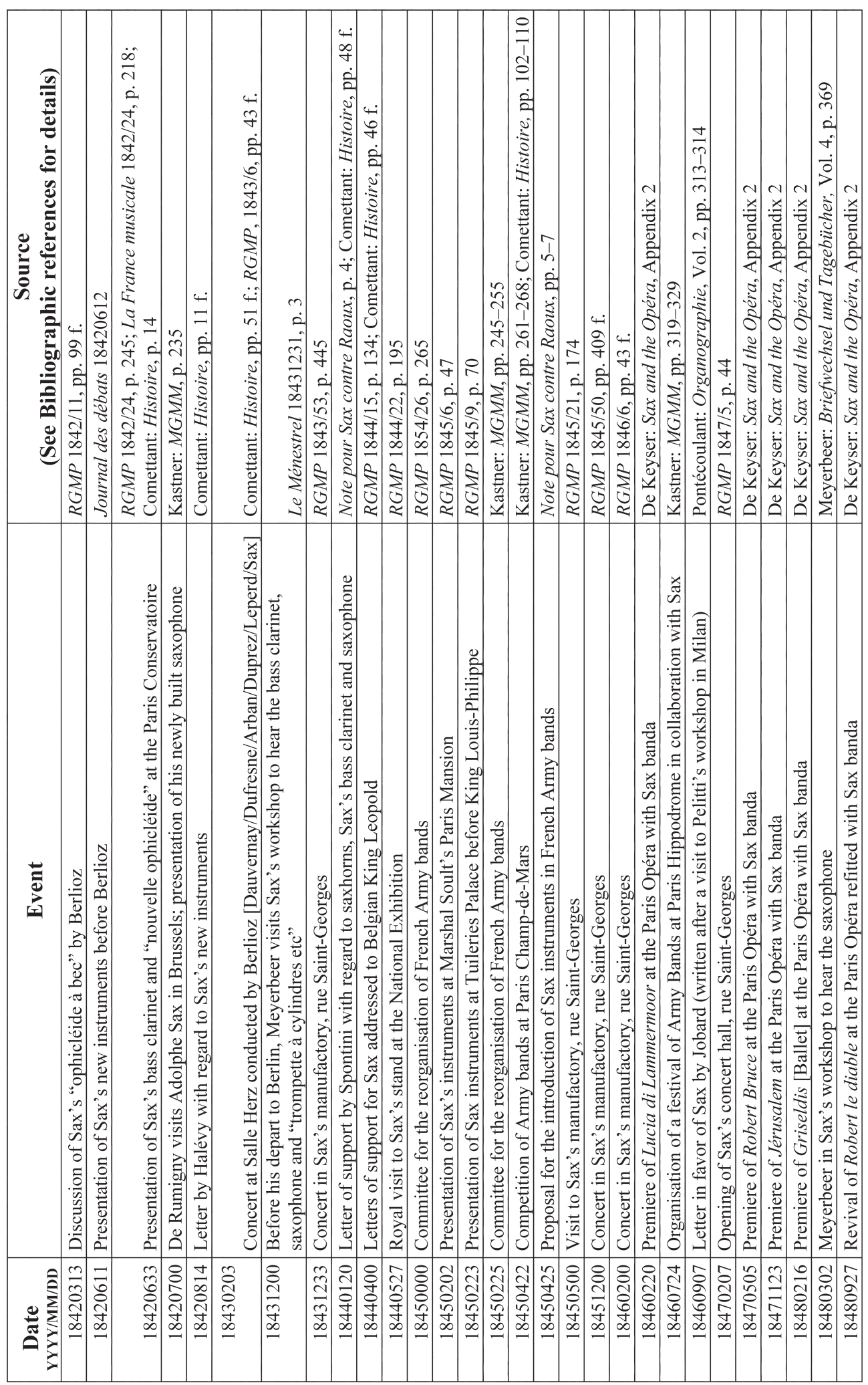

TAB LE 4 Dates, description and sources of events. "oo" in a date means

"unknown month/day"; " 33 " in a date means "at the end of the month". 


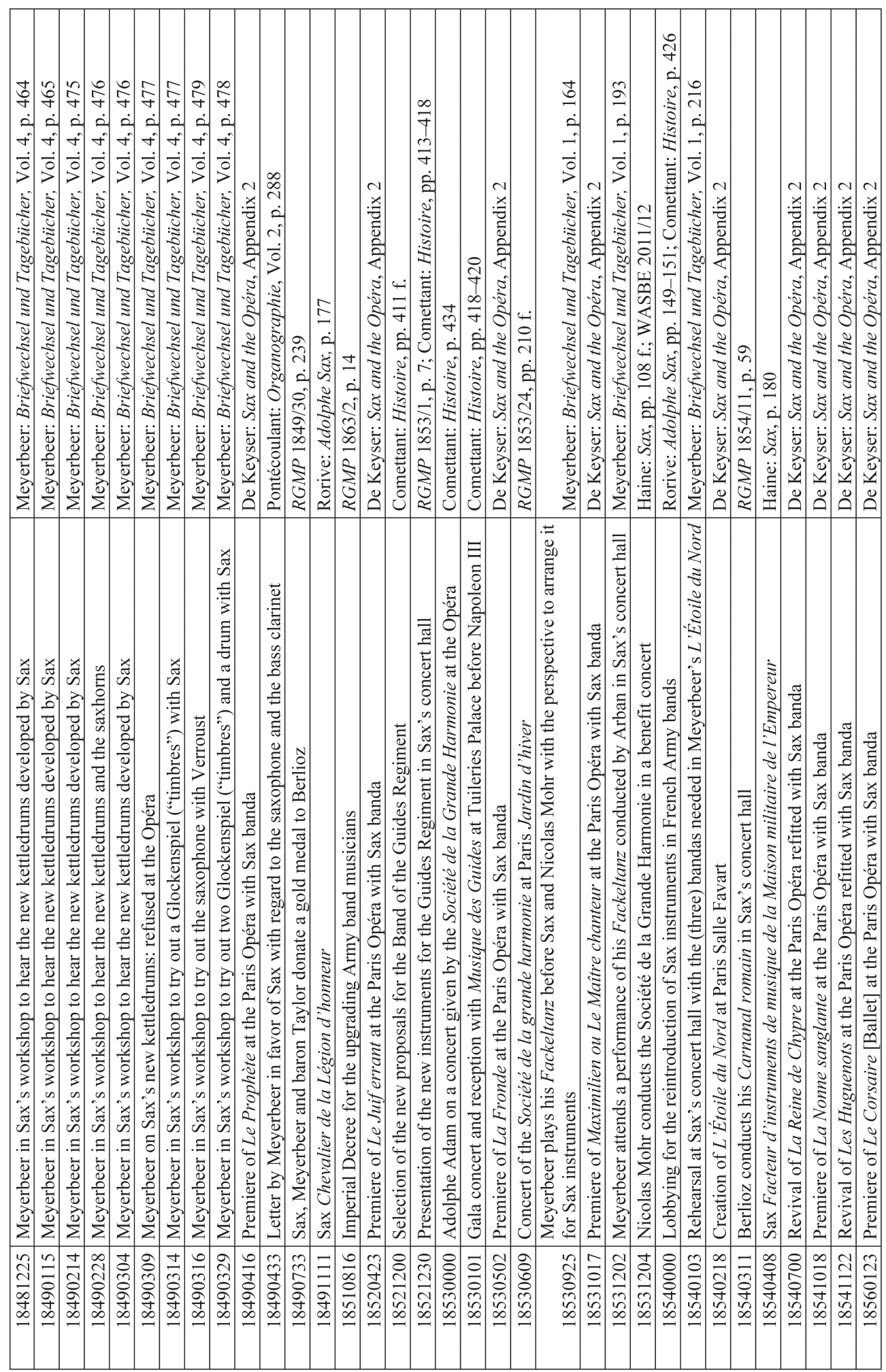




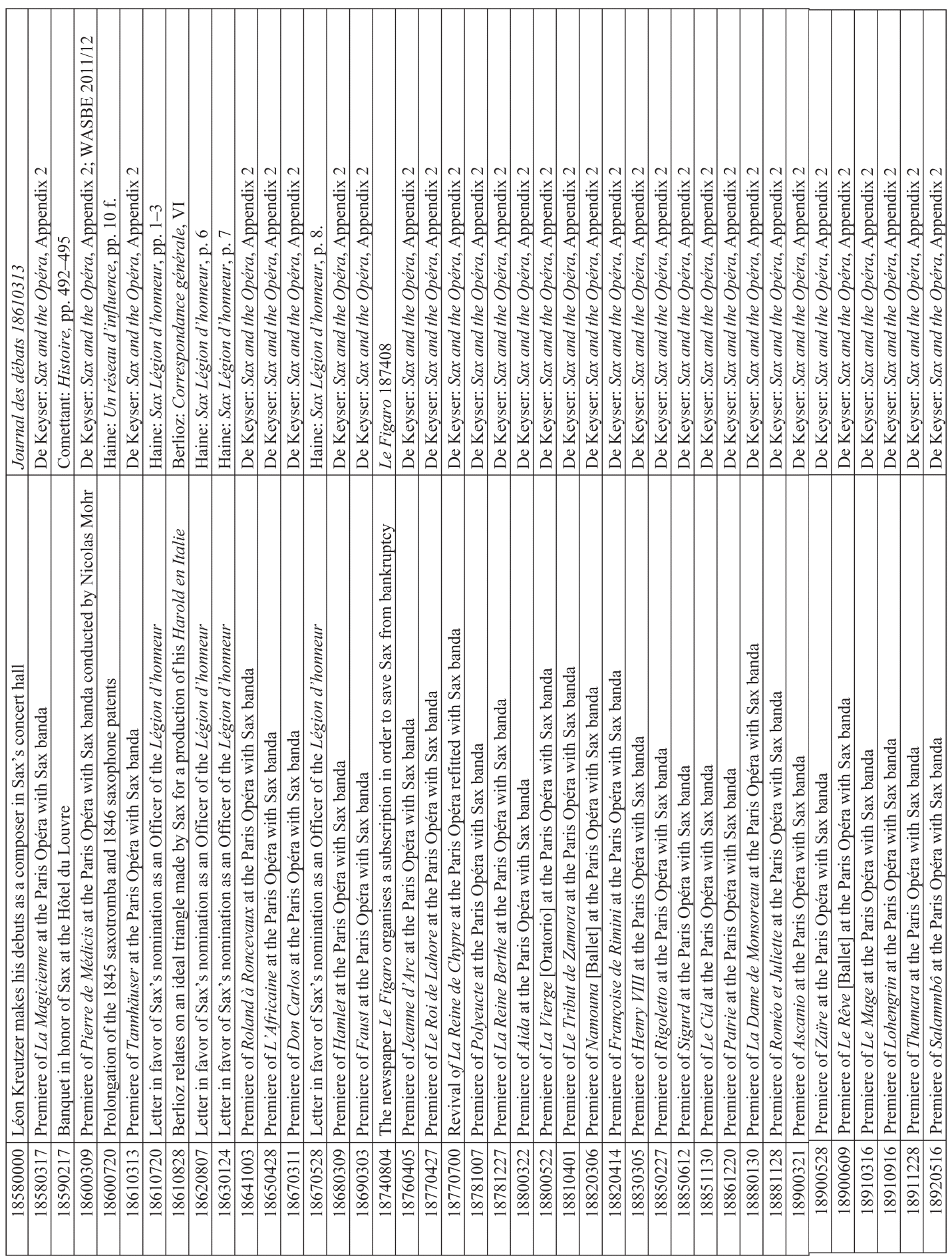




\begin{tabular}{|c|c|}
\hline Abbreviation & Bibliographic references \\
\hline Arban & $\begin{array}{l}\text { Jean-Baptiste Arban/Alexandre Fessy: Méthode complète des saxhorns alto et ténor, } \\
\text { Paris: E. Troupenas \& Cie [1845]; J.-B. Arban: Grande méthode du cornet à pistons et } \\
\text { de saxhorn, Paris: Escudier [1864]; Id.: Petite méthode élémentaire pour le cornet à } 3 \\
\text { pistons, Paris: Ad. Sax [1867]. }\end{array}$ \\
\hline Berlioz: Correspondance générale, VI & $\begin{array}{l}\text { Hector Berlioz: Correspondance générale, Vol. VI, September 1859-1863, ed. by } \\
\text { Pierre Citron/Hugh J. Macdonald/François Lesure, Paris 1995, p. } 245 .\end{array}$ \\
\hline Berlioz: Rapport 1851 & $\begin{array}{l}\text { Hector Berlioz: Rapport sur les instruments de musique, fait à la commission française } \\
\text { du Jury international de l'exposition universelle de Londres (1851), Paris } 1854 .\end{array}$ \\
\hline Berlioz: Grand traité 1855 & $\begin{array}{l}\text { Hector Berlioz: Grand traité d'instrumentation et d'orchestration modernes, Nouvelle } \\
\text { édition, Paris/Bruxelles: Henry Lemoine \& Cie [1855]. }\end{array}$ \\
\hline Comettant: Histoire & $\begin{array}{l}\text { Oscar Comettant: Histoire d'un inventeur au XIXe siècle. Adolphe Sax, ses ouvrages et } \\
\text { ses luttes, Paris } 1860 .\end{array}$ \\
\hline De Keyser: Sax and the Opéra & $\begin{array}{l}\text { Ignace De Keyser: Adolphe Sax and the Paris Opéra, in: Brass Scholarship in Review. } \\
\text { Proceedings of the Historic Brass Society Conference at the Cité de la Musique, Paris } \\
\text { 1999, Hillsdale (NY) 2006, pp. 133-169. }\end{array}$ \\
\hline Pontecoulant: Organographie & $\begin{array}{l}\text { Adolphe Le Doulcet de Pontécoulant: Organographie. Essai sur la facture } \\
\text { instrumentale. Art, industrie et commerce, Vol. } 1 \text { \& 2, Paris } 1861 .\end{array}$ \\
\hline Fétis & $\begin{array}{l}\text { François-Joseph Fétis: Nouvelles clarinettes de M. Sax fils, in: Revue et gazette } \\
\text { musicale de Paris, Vol. 8, No. } 2 \text { (7 January 1841), pp. } 9 \text { f., \& No. } 3 \text { (10 January 1841), } \\
\text { pp. } 19 \text { f.; Id.: De l'organisation des musiques militaires et des instruments du système } \\
\text { de Sax, in: Revue et gazette musicale de Paris, Vol. 15, No. } 50 \text { (10 December 1848), pp. } \\
\text { 382-384; Id.: Exposition Universelle de Londres, in: Revue et gazette musicale de } \\
\text { Paris, Vol. 18, Nos. 34-51 (August-December 1851), pp. 273-411 (passim) \& Vol. 19, } \\
\text { Nos. 1-10, p. 3-75 (passim); Id.: Exposé historique de la formation et des variations de } \\
\text { systèmes de la fabrication des Instruments de musique, in: Exposition Universelle de } \\
\text { 1855. Rapports du jury mixte international publiés sous la direction de S. A. I. le Prince } \\
\text { Napoléon, Paris 1856, Vol. II, pp. 657-708; Id.: Lettre à Georges Kastner, in: Revue et } \\
\text { gazette musicale de Paris, Vol. 26, No. } 45 \text { (6 November 1859), pp. 370-372; Id.: } \\
\text { Exposition Internationale de Londres 1862, in: Revue et gazette musicale de Paris, Vol. } \\
\text { 29, Nos. 24-45 (June-November 1862), pp 193-363 (passim); Id.: Sax, in: Biographie } \\
\text { universelle des musiciens et bibliographie générale de la musique. Deuxième édition, } \\
\text { Paris 1867, Vol. 7, pp. 413-423. }\end{array}$ \\
\hline Forestier & $\begin{array}{l}\text { Joseph Forestier: Méthode complète pour les sax-horns ou bugles, ou sax-tromba ou } \\
\text { trombone-alto à } 3 \text { cylindres adoptée pour l'enseignement au Gymnase musical } \\
\text { militaire, Paris: Meissonnier et fils [1846]; Id.: Petite méthode de cornet à pistons à } \\
\text { l'usage des commençants, Paris: E. Gérard \& Cie [1864]; Id.: Petite méthode pour } \\
\text { saxhorn soprano, contralto, alto ou ténor et baryton à l'usage des commençants, Paris: } \\
\text { E. Gérard \& Cie [1868]; Id.: Monographie des instruments à six pistons et tubes } \\
\text { indépendants. Etudes pratiques et théoriques pour le nouveau système de M. Adolphe } \\
\text { Sax, Paris: Adolphe Sax [1870]. }\end{array}$ \\
\hline Haine: Sax & $\begin{array}{l}\text { Malou Haine: Adolphe Sax (1814-1894). Sa vie, son cuvre et ses instruments de } \\
\text { musique, Brussels } 1980 .\end{array}$ \\
\hline Haine: Un réseau d'influence & $\begin{array}{l}\text { Malou Haine: Un réseau d'influence. Les démarches d'Adolphe Sax pour obtenir la } \\
\text { croix d'officier de la Légion d'honneur, in: Revue belge de musicologie } 70 \text { (2016), pp. } \\
\text { 9-22. }\end{array}$ \\
\hline Halévy: Rapport d'expertise & $\begin{array}{l}\text { François Halévy/Nicolas Savart/Nicolas Boquillon: Affaire Sax. Rapport d'expertise } \\
\text { [...] dans le procès en déchéance intenté contre les brevets Sax, par MM. Raoux, } \\
\text { Halary, Gautrot, Gambard [sic], Buffet, etc., délégués des facteurs français, Paris } \\
1848 .\end{array}$ \\
\hline Jobard: Exposition 1839 & $\begin{array}{l}\text { Jean Baptiste Ambroise Marcellin Jobard: Industrie française. Rapport sur l'exposition } \\
\text { de 1839, Brussels/Paris } 1841 \text { (Vol. 1) \& } 1842 \text { (Vol. 2). }\end{array}$ \\
\hline Journal des débats 18420612 & $\begin{array}{l}\text { Hector Berlioz: Feuilleton. Instruments de musique. M. Ad. Sax, in: Journal des débats } \\
\text { politiques et littéraires, } 12 \text { June } 1842, \text { p. [iii]. }\end{array}$ \\
\hline
\end{tabular}

TABLE 5 Bibliographic sources 


\begin{tabular}{|c|c|}
\hline Kastner: $M G M M$ & $\begin{array}{l}\text { Georges Kastner: Manuel général de musique militaire à l'usage des armées françaises, } \\
\text { Paris } 1848 .\end{array}$ \\
\hline Kastner: Supplément & $\begin{array}{l}\text { Georges Kastner: Supplément au Traité général d'instrumentation, Paris: Prilipp et Cie } \\
\text { [1844]. }\end{array}$ \\
\hline Kastner & 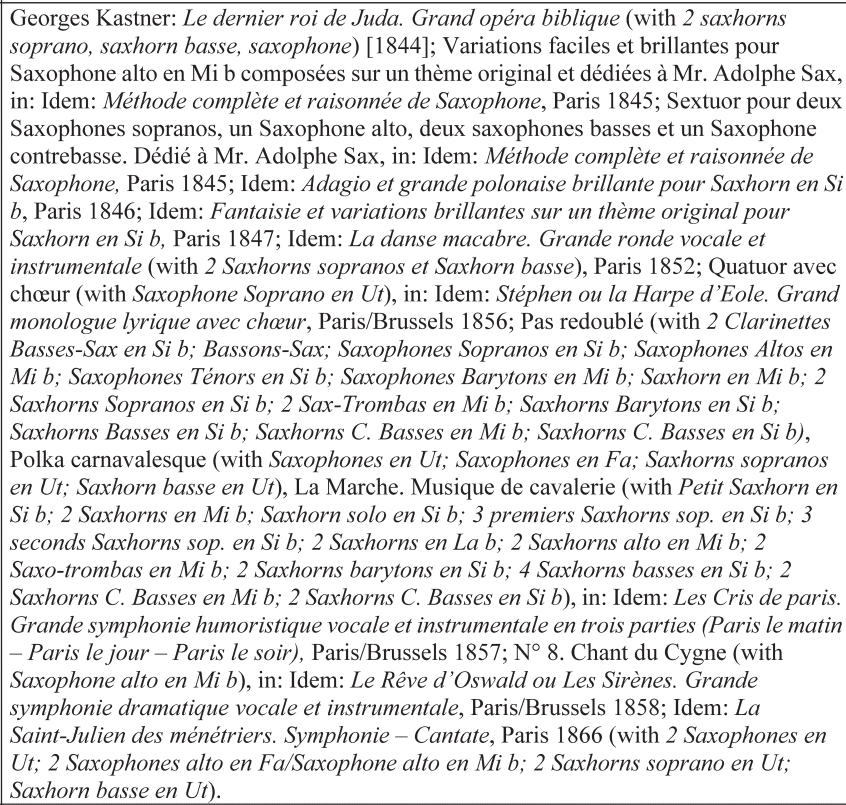 \\
\hline La France musicale 1842/24, p. 218. & Nouvelles, in: La France musicale, Vol. 5, No. 24 (12 June 1842), p. 218. \\
\hline La France musicale, $1843 / 35$, p. 277-278. & $\begin{array}{l}\text { Castil-Blaze: Adolphe Sax, in: La France musicale, Vol. 6, No. } 35 \text { (27 August 1843), } \\
\text { pp. 277-278. }\end{array}$ \\
\hline La Quotidienne 18450109 & $\begin{array}{l}\text { Léon Kreutzer: Feuilleton. Revue musicale, in: La Quotidienne, } 9 \text { January 1845, pp. } \\
\text { [i]-[ii]. }\end{array}$ \\
\hline La Quotidienne 18450511 & $\begin{array}{l}\text { Léon Kreutzer: Feuilleton. Revue musicale, in: La Quotidienne, } 11 \text { May 1845, pp. } \\
\text { [i]-[ii]. }\end{array}$ \\
\hline Le Constitutionel 18470307 & $\begin{array}{l}\text { Pier Angelo Fiorentino: Feuilleton. Revue musicale, in: Le Constitutionnel, } 7 \text { March } \\
\text { 1847, pp. [i]-[ii]. }\end{array}$ \\
\hline Le Figaro 187408 & $\begin{array}{l}\text { Alfred d'Aunay: Adolphe Sax, in: Le Figaro, } 4 \text { August 1874, p. [i]; Souscription Sax, } \\
\text { in: Le Figaro, 4, 5, } 7 \text { \& } 10 \text { August 1874, p. [i]. }\end{array}$ \\
\hline Le Ménestrel 18490429 & $\begin{array}{l}\text { Edmond Viel: Théâtre de la Nation. Le Prophète. } 3^{\mathrm{e}} \text { article. La Partition, in: Le } \\
\text { Ménestrel, Vol. 16, No. } 22 \text { (29 April 1849), pp. [i]-[iii]. }\end{array}$ \\
\hline Le Ménestrel 18531211 & $\begin{array}{l}\text { Edmond Viel: La Marche aux flambeaux de Meyerbeer. La société de la Grande } \\
\text { harmonie, in: Le Ménestrel, Vol. 21, No. } 2 \text { (11 December 1853), pp. [i]-[ii]. }\end{array}$ \\
\hline Le Monde illustré 18630103 & $\begin{array}{l}\text { Auguste Luchet: Courrier de l'Exposition internationale. M. Adolphe Sax, in: Le } \\
\text { Monde illustré, Vol. 7, No. } 299 \text { (3 January 1863), pp. 11-14. }\end{array}$ \\
\hline Le Monde illustré 18641119 & $\begin{array}{l}\text { Auguste Luchet: Exposition franco-espagnole de Bayonne. M. Adolphe Sax, in: Le } \\
\text { Monde illustré, Vol. 8, No. } 397 \text { (19 November 1864), pp. 335-336. }\end{array}$ \\
\hline Le Monde illustré 18670810 & $\begin{array}{l}\text { Auguste Luchet: Courrier de l'Exposition universelle. XXII. La vitrine de M. Adolphe } \\
\text { Sax, in: Le Monde illustré, Vol. 11, No. } 539 \text { (10 August 1867), p. } 91 .\end{array}$ \\
\hline Le Monde illustré 18671130 & $\begin{array}{l}\text { Auguste Luchet: Courrier de l'Exposition universelle. XXXVIII. Les inventions de M. } \\
\text { Adolphe Sax, in: Le Monde illustré, Vol 11, No. } 555 \text { (30 November 1867), pp. } \\
\text { 339-342. }\end{array}$ \\
\hline Le Temps 18670404 & $\begin{array}{l}\text { Johannès Weber: Feuilleton [La fanfare de Don Carlos - Le dernier terme du système } \\
\text { de pistons], in: Le Temps, } 4 \text { April 1867, pp. [i] \& [iii]. }\end{array}$ \\
\hline
\end{tabular}




\begin{tabular}{|c|c|}
\hline L'Indépendant 18440121, p. 1-2. & $\begin{array}{l}\text { E. V. [Edmond Viel]: M. Sax, in: L'Indépendant, Furet des Théâtres, } 21 \text { January 1844, } \\
\text { pp. 1-2. }\end{array}$ \\
\hline Meyerbeer: Briefwechsel und Tagebücher & $\begin{array}{l}\text { Giacomo Meyerbeer: Briefwechsel und Tagebücher, ed. by Sabine } \\
\text { Henze-Döhring/Panja Mücke, Berlin 1959-2012, } 8 \text { vol. }\end{array}$ \\
\hline Note pour Sax contre Raoux & $\begin{array}{l}\text { Adolphe Sax: Note pour M. Sax, appelant, contre MM. Raoux et consorts, intimés. Cour } \\
\text { impériale de Rouen, Paris: Simon Dautreville [1854]. }\end{array}$ \\
\hline RGMP 1842/11, pp. 99-100. & $\begin{array}{l}\text { Hector Berlioz: De l'instrumentation (Onzième article), in: Revue et gazette musicale } \\
\text { de Paris, Vol. 9, No. } 11 \text { (6 March 1842), pp. 99-100. }\end{array}$ \\
\hline RGMP 1842/24, p. 245. & Nouvelles, in: Revue et gazette musicale de Paris, Vol 9, No. 24 (12 June 1842), p. 245. \\
\hline RGMP 1843/37, pp. 314-316. & $\begin{array}{l}\text { Henri Blanchard: Adolphe Sax, in: Revue et gazette musicale de Paris, Vol. 10, No. } 37 \\
\text { (10 September 1843), pp. 314-316. }\end{array}$ \\
\hline$R G M P 1845 / 17$, pp. 134-135. & $\begin{array}{l}\text { Maurice Bourges: Musique militaire. Concours au Champ-de-Mars, in: Revue et gazette } \\
\text { musicale de Paris, Vol. 12, No. } 17 \text { (27 April 1845), pp. 134-135. }\end{array}$ \\
\hline RGMP 1845/39, pp. 316-319. & $\begin{array}{l}\text { Léon Kreutzer: Nouvelle organisation des musiques militaires, in: Revue et gazette } \\
\text { musicale de Paris, Vol. 12, No. } 39 \text { (28 September 1845), pp. 316-319. }\end{array}$ \\
\hline RGMP 1845/50, pp. 409_410. & $\begin{array}{l}\text { Léon Kreutzer: Séance musicale chez M. A. Sax, in: Revue et gazette musicale de Paris, } \\
\text { Vol. 12, No. } 50 \text { (14 December 1845), pp. 409-410. }\end{array}$ \\
\hline RGMP 1846/6, pp. 43-44. & $\begin{array}{l}\text { Maurice Bourges: Une fête chez M. Adolphe Sax, in: Revue et gazette musicale de } \\
\text { Paris, Vol. 13, No. } 6 \text { ( } 8 \text { February 1846), pp. 43-44. }\end{array}$ \\
\hline RGMP 1847/22, p. 182. & $\begin{array}{l}\text { Henri Blanchard: Une soirée musicale chez M. Sax, in: Revue et gazette musicale de } \\
\text { Paris, Vol. 14, No. } 22 \text { (30 May 1847), p. } 182 .\end{array}$ \\
\hline RGMP 1849/30, p. 239. & $\begin{array}{l}\text { Nouvelles, in: Revue et gazette musicale de Paris, Vol. 16, No. } 30 \text { (29 July 1849), p. } \\
239 .\end{array}$ \\
\hline RGMP 1849/32, pp. 253-255. & $\begin{array}{l}\text { Henri Blanchard: Exposition des produits de l'industrie. Troisième article. MM. Erard, } \\
\text { Sax, Bartch, Baneux, Pape, Boisselot, Lété, Herz, in: Revue et gazette musicale de } \\
\text { Paris, Vol. 16, No. } 32 \text { (12 August 1849), pp. 253-255. }\end{array}$ \\
\hline RGMP 1849/52, p. 416. & $\begin{array}{l}\text { Nouvelles, in: Revue et gazette musicale de Paris, Vol. 16, No. } 52 \text { (30 December 1849), } \\
\text { p. } 416 .\end{array}$ \\
\hline RGMP 1850/20, p. 171. & $\begin{array}{l}\text { Léon Kreutzer: Soirée de musique d'harmonie, chez M. Sax, in: Revue et gazette } \\
\text { musicale de Paris, Vol. 17, No. } 20 \text { (19 May 1850), p. } 171 .\end{array}$ \\
\hline RGMP $1853 / 24$, pp. 210-211. & $\begin{array}{l}\text { Léon Kreutzer: Société de la Grande Harmonie, au Jardin d'hiver, in: Revue et gazette } \\
\text { musicale de Paris, Vol. 20, No. } 24 \text { (12 June 1853), pp. 210-211. }\end{array}$ \\
\hline$R G M P 1853 / 30$, pp. 261-262. & $\begin{array}{l}\text { Léon Kreutzer: Concert de la musique Sax à Lille, in: Revue et gazette musicale de } \\
\text { Paris, Vol. 20, No. } 30 \text { (24 July 1853), pp. 261-262. }\end{array}$ \\
\hline$R G M P 1853 / 32$, pp. $275-276$. & $\begin{array}{l}\text { Léon Kreutzer: Concert organisé à Lille pour la Société Sax, in: Revue et gazette } \\
\text { musicale de Paris, Vol. 20, No. } 32 \text { (7 August 1853), pp. 275-276. }\end{array}$ \\
\hline RGMP 1853/43, p. 374. & $\begin{array}{l}\text { Henri Blanchard: Une audition de la Musique des Guides chez Adolphe Sax, in: Revue } \\
\text { et gazette musicale de Paris, Vol. 20, No. } 43 \text { ( } 23 \text { October 1853), p. } 374 .\end{array}$ \\
\hline RGMP $1854 / 26$, pp. 207-209. & $\begin{array}{l}\text { Léon Kreutzer: Organisation des musiques des Chasseurs à pied, in: Revue et gazette } \\
\text { musicale de Paris, Vol. 21, No. } 26 \text { (25 June 1854), pp. 207-209. }\end{array}$ \\
\hline RGMP 1854/29, p. 231. & $\begin{array}{l}\text { Henri Blanchard: Audition des instruments de Sax, in: Revue et gazette musicale de } \\
\text { Paris, Vol. 21, No. } 29 \text { (16 July 1854), p. } 231 .\end{array}$ \\
\hline Rorive: Adolphe Sax & Jean-Pierre Rorive: Adolphe Sax 1814-1894. Inventeur de génie, Brussels 2004. \\
\hline WASBE 2011/12 & $\begin{array}{l}\text { Francis Pieters: ERRATUM concerning MOHR, in: WASBE WORLD. Official } \\
\text { Magazine of the World Association for Symphonic Bands and Ensembles, December } \\
\text { 2011, p. } 23 \text {. }\end{array}$ \\
\hline WASBE 2012/12 & $\begin{array}{l}\text { Francis Pieters: Giacomo Meyerbeer and the wind band, in: WASBE WORLD. Official } \\
\text { Magazine of the World Association for Symphonic Bands and Ensembles, December } \\
\text { 2012, pp. 14-28. }\end{array}$ \\
\hline
\end{tabular}

TAB LE 6 (opposite side) Neologisms for musical instruments using the name of the inventor. This list is based on information gathered from Christian Ahrens: Fast vergessene Blasinstrumente aus zwei Jahrhunderten. Vom Albisiphon zur Zugtrompete, Nauheim 1982; Dr. Francesco Carreras (Pisa), personal communication and idem: Combination Clarinet Patents in Italy, in: Journal of the American

Musical Instrument Society 37 (2012), pp. 6-33; Malou Haine/Nicolas Meeùs: Dictionnaire des facteurs d'instruments de musique en Wallonie et à Bruxelles du $9^{e}$ siècle à nos jours, Liège 1986; Malou Haine: Les facteurs d'instruments de musique à Paris; Herbert Heyde: Das Ventilblasinstrument; Bruno Kampmann: Le Saxophone "Système Georges", in: Larigot 26 (May 2006), pp. 20-26; William Waterhouse: The New Langwill Index. A Dictionary of Musical Wind-Instrument Makers and Inventors, London 1993; The New Grove Dictionary of Musical Instruments, ed. by Stanley Sadie, London 1984; and The Grove Dictionary of Musical Instruments. Second Edition, ed. by Laurence Libin, Oxford 2014 . 


\begin{tabular}{|c|c|c|c|}
\hline $\begin{array}{l}\text { Earliest } \\
\text { mention }\end{array}$ & Name & Inventor & Type \\
\hline 1577 & Bassanello & Giovanni ( ?) Bassano & Double reed instrument \\
\hline 1801 & Schollbasso & Franz Scholl (fl. 1792-post 1804) & Bass clarinet \\
\hline 1823 & Basson Forveille & Forveille (fl. 1823-1839) & Upright serpent \\
\hline 1825 & Tuba Dupré & Joseph Dupré (1790-1862) & Wooden ophicleide \\
\hline 1841 & Saxophone & Adolphe Sax (1814-1894) & Conical single reed instrument \\
\hline 1844 & Saxhorn & Idem & Conical brasswind \\
\hline 1844 & Pelittifono & Giuseppe Pelitti (1811-1865) & Valved wooden ophicleide \\
\hline 1844 & Mattauphone & Jean-Baptiste Mattau (1788-1867) & Glass armonica \\
\hline 1845 & Pelitticorno & G. Pelitti & Valved wooden horn \\
\hline 1845 & Saxotromba & A. Sax & Conical brasswind \\
\hline 1845 & Pelittone & G. Pelitti & Conical brasswind \\
\hline 1845 & Hell-horn & Ferdinand Hell (1810-c1875) & Conical brasswind \\
\hline 1846 & Clairon-Sax & A. Sax & Cavalry bugle with removable valves \\
\hline $\mathrm{c} 1850$ & Bimbonifono & Gioacchino Bimboni (1810-1895) & Upright trombone \\
\hline 1850 & Bimbonclarino & Idem & Bass clarinet \\
\hline 1851 & Sommerphon & F. Sommer (?) & Conical brasswind \\
\hline 1852 & Saxtuba & A. Sax & Conical brasswind \\
\hline 1853 & Meloni-Cor & Luigi Giuseppe Cassi-Meloni (?) & Duplex free reed instrument \\
\hline 1854 & Bandoneon & Heinrich Band (1821-1860) & Accordion \\
\hline 1855 & Müllerphone & Louis Müller (c1835-1867) & Double bass clarinet \\
\hline 1855 & Koenighorn & Koenig [but made by Courtois] & Conical brasswind \\
\hline 1856 & Sarrusophone & Pierre-Auguste Sarrus (1813-1876) & Conical double reed instrument \\
\hline 1857 & Cassi-Flûte & L. G. Cassi-Meloni & Flute \\
\hline 1865 & Melodipiano Caldera & Luigi Caldera (?) & Adapted piano \\
\hline 1866 & Maldura Clarone & Alessandro Maldura (fl. 1850-post 1914) & Double bass clarinet in $\mathrm{Eb}$ \\
\hline 1867 & Antoniophone & Antoine Courtois $(\uparrow 1880)$ & Bombardon with detachable bell \\
\hline 1867 & Georgeophone & Claude George (?) & Variant of the saxophone \\
\hline 1889 & Heckel-Clarina & Wilhelm Heckel (1856-1909) & Conical single reed instrument \\
\hline 1873 & Bussophone & Pierre Busson (?) & Mechanical instrument \\
\hline 1874 & Landriëno & Gustavo Landriëno (?) & Music reproduction device for piano \\
\hline 1877 & Gabusifono & Giuseppe Gabusi (?) & Tuba type of a valve trombone \\
\hline 1877 & Clarinetto Parra & Antonio di Lupo Parra (1831-1879) & Clarinet with upright bell \\
\hline 1879 & $\begin{array}{l}\text { Tastiera cromatica Grassi- } \\
\text { Landi }\end{array}$ & Bartolomeo Grassi-Landi (?) & Adapted keyboard \\
\hline 1883 & Melopiano Caldera & L. Caldera & Adapted piano \\
\hline 1886 & Arpa italiana Caldera & Idem & Adapted harp \\
\hline 1886 & Giorgi flute & Carlo Tomaso Giorgi (1856-1953) & Cylindrical vertical flute \\
\hline 1890 & Sousaphone & John Philip Sousa (1854-1932) & Bombardon with front bell \\
\hline 1892 & Sudrophone & François Sudre (1844-c1912) & Conical brasswind with mirliton \\
\hline 1893 & Quinardophone & Quinard (?) & Conical brasswind \\
\hline 1894 & Tanaka-clarinet & Shohé Tanaka (1862-1945) & Clarinet with keyboard \\
\hline 1898 & $\begin{array}{l}\text { Martinophone/ } \\
\text { Martin Schalmei }\end{array}$ & Max B. Martin (?) & Free reed instrument with valves \\
\hline 1900 & Rothphone & Ferdinand Roth (1815-1898) & Family of double reeds \\
\hline 1901 & Sediphone & Joseph Sediva (1853-1915) & Duplex brasswind \\
\hline 1904 & Helckelphon & W. Heckel \& Sons & Conical double reed instrument \\
\hline 1907 & Heckelphonklarinette & Idem & Conical single reed instrument \\
\hline 1910 & Albisiphone & Abelardo Albisi (1827-1937) & Bass flute \\
\hline $1912 ?$ & Rothcorno & Fratelli Bottali (fl. post 1898-ante 1939) & A saxhorn in horn shape \\
\hline 1920 & $\begin{array}{l}\text { Aetherphon/Theremin/ } \\
\text { Termenvoksa }\end{array}$ & Lev Theremin (1896-1993) & $\begin{array}{l}\text { First fully electronic device for music } \\
\text { making (ring modulator) }\end{array}$ \\
\hline 1922 & Ondes Martenot & Maurice Martenot (1898-1980) & $\begin{array}{l}\text { Monophonic electronic instrument } \\
\text { (ring modulator) }\end{array}$ \\
\hline 1930 & Trautonium & Friedrich Trautwein (1888-1956) & $\begin{array}{l}\text { Monophonic electronic instrument } \\
\text { (ring modulator controlled by a wire) }\end{array}$ \\
\hline 1964 & Moog synthesizer & Robert A. Moog (1934-2005) & $\begin{array}{l}\text { Monophonic electronic instrument } \\
\text { (the first that uses Vladimir } \\
\text { Usachevsky's envelope generator) }\end{array}$ \\
\hline $1960-$ & Buchla $200 / 300 / 400$ etc. & Donald Frederick Buchla $\left({ }^{*} 1937\right)$ & $\begin{array}{l}\text { Synthesizers (among them the first to } \\
\text { to implement MIDI) }\end{array}$ \\
\hline 1993 & Alessofono & $\begin{array}{l}\text { Alessi [Design by Alessandro Mendini \& } \\
\text { M. Christina Hamel] }\end{array}$ & $\begin{array}{l}\text { A new saxophone design with a. } \mathrm{o} \text {. } \\
\text { extended key levers }\end{array}$ \\
\hline
\end{tabular}




\section{Inhalt}

Vorwort 7

Adrian von Steiger "Agilité, homogénéité et beauté". The Saxhorn in the Context of the Opéra and Military Music 9

Eugenia Mitroulia/Arnold Myers The Saxhorn Families I8

Malou Haine Une nouvelle source d'archives pour identifier les marques de fabrique de facteurs d'instruments de musique (I860 à I9I9)

Stewart Carter Kastner, the Distin Family, and the Emergence of the "New" Brasswind Instruments by Adolphe Sax 68

Sabine K. Klaus Wieprecht versus Sax. German Roots of Adolphe Sax's Brasswind Designs 97

Ignace De Keyser The Construction of the Genius in

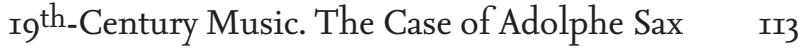

Cyrille Grenot Deux faillites d'Adolphe Sax, I873 et I877. Présentation et documents $\quad$ I46

Reimar Walthert The First Twenty Years of Saxhorn Tutors $\quad 155$

Bruno Kampmann French Makers' Improvements on Brass Instruments in the mid-I th $^{\text {th }}$ Century, Compared with Those by Adolphe Sax $\quad$ I68

Jeroen Billiet Adolphe Sax's Ultimate Masterpiece. The History, Design and Use of the Cor Sax à six pistons indépendants $\quad$ I76

Daniel Allenbach „Une réforme tellement logique« oder »à classer au rang des utopies«? Henri Chaussiers »instruments en Ut« $\quad$ I88

Gregor Widholm Das Wiener Horn - ein Instrument des I9. Jahrhunderts als erste Wahl in Orchestern des 2I. Jahrhunderts 223

Martin Skamletz »... und gar nichts, wodurch sich der eigene schöpferische Geist des Komponisten beurkundete«. Cherubini, Hummel, Konzerte, Opern, Quodlibetes und Trompeten in Wien zu Beginn des I9. Jahrhunderts.

Teil 3 und Schluss: Anton Weidinger und sein Instrument 245

Rainer Egger/Martin Mürner $\quad$ Restaurierungsergebnisse messbar machen $\quad 262$ Namen-, Werk- und Ortsregister 272

Die Autorinnen und Autoren der Beiträge $\quad 283$ 


\section{DAS SAXHORN}

Adolphe Sax' Blechblasinstrumente im Kontext ihrer

Zeit. Romantic Brass Symposium 3 - Herausgegeben von Adrian von Steiger, Daniel Allenbach und Martin Skamletz 


\section{MUSIKFORSCHUNG DER Hochschule der KÜnste Bern Herausgegeben von Martin Skamletz und Thomas Gartmann}

Band 13 
2 Dieses Buch ist in gedruckter Form im April 2020 in erster Auflage in der Edition Argus in Schliengen/Markgräflerland erschienen. Gestaltet und gesetzt wurde es im Verlag aus der Seria und der SeriaSans, die von Martin Majoor im Jahre 2000 gezeichnet wurden. Gedruckt wurde es auf Eos, einem holzfreien, säurefreien, chlorfreien und alterungsbeständigen Werkdruckpapier der Papierfabrik Salzer im niederösterreichischen Sankt Pölten. Das Vorsatzpapier Caribic cherry wurde von Igepa in Hambug geliefert. Rives Tradition, ein Recyclingpapier mit leichter Filznarbung, das für den Bezug des Umschlags verwendet wurde, stellt die Papierfabrik Arjo Wiggins in Issy-les-Moulineaux bei Paris her. Das Kapitalband mit rot-schwarzer Raupe lieferte die Firma Dr. Günther Kast aus Sonthofen im Oberallgäu, die auf technische Gewebe und Spezialfasererzeugnisse spezialisiert ist. Gedruckt und gebunden wurde das Buch von der Firma Bookstation im bayerischen Anzing. Im Internet finden Sie Informationen über das gesamte Verlagsprogramm unter www.editionargus.de, zum Institut Interpretation der Hochschule der Künste Bern unter www.hkb.bfh.ch/interpretation und www.hkb-interpretation.ch. Die Deutsche Nationalbibliothek verzeichnet diese Publikation in der Deutschen Nationalbibliografie; detaillierte bibliografische Daten sind im Internet über www.dnb.de abrufbar. (C) der zeitgleich erschienenen digitalen Version: die Autorinnen und Autoren, 2020. Dieses Werk ist lizenziert unter einer Creative Commons Namensnennung-Nicht kommerziell 4.0 International Lizenz (CC BY-NC 4.o). DOI: https://doi.org/I0.26045/kp64-6I77 ISBN 978-3-93I264-93-2 